University of Rhode Island

DigitalCommons@URI

Open Access Master's Theses

2020

\title{
COMBINED EFFECT OF HERBIVORY AND SALINITY STRESS ON THE COMMON REED, PHRAGMITES AUSTRALIS
}

Jennifer Soukup

University of Rhode Island, jvsoukup29@gmail.com

Follow this and additional works at: https://digitalcommons.uri.edu/theses

\section{Recommended Citation}

Soukup, Jennifer, "COMBINED EFFECT OF HERBIVORY AND SALINITY STRESS ON THE COMMON REED, PHRAGMITES AUSTRALIS" (2020). Open Access Master's Theses. Paper 1905.

https://digitalcommons.uri.edu/theses/1905

This Thesis is brought to you for free and open access by DigitalCommons@URI. It has been accepted for inclusion in Open Access Master's Theses by an authorized administrator of DigitalCommons@URI. For more information, please contact digitalcommons-group@uri.edu. 
COMBINED EFFECT OF HERBIVORY AND SALINITY STRESS ON

THE COMMON REED, PHRAGMITES AUSTRALIS

BY

JENNIFER SOUKUP

A THESIS SUBMITTED IN PARTIAL FULFILLMENT OF THE

REQUIREMENTS FOR THE DEGREE OF

MASTER OF SCIENCE

IN

BIOLOGICAL AND ENVIRONMENTAL SCIENCES

WITH A SPECIALIZATION IN

ECOLOGY AND ECOSYSTEMS SCIENCES

UNIVERSITY OF RHODE ISLAND 


\section{MASTER OF SCIENCE}

OF

JENNIFER SOUKUP

APPROVED:

Thesis Committee:

Major Professor:

Laura A Meyerson

Jose Amador

James T Cronin

Brenton DeBoef

DEAN OF THE GRADUATE SCHOOL

UNIVERSITY OF RHODE ISLAND

2020 


\begin{abstract}
With the rapid decline of Phragmites australis in the Mississippi River Delta (MRD) and increasing threat of land erosion, understanding the possible contributing factors to reed dieback have become increasingly apparent. In this study, we use a greenhouse experiment to examine how the combination of salinity and herbivory could contribute to carbon starvation and ultimately reed dieback in reed stands of North American native and/or the introduced European in New England wetlands. We measured the aboveground biomass, leaf water content, leaf toughness, and specific leaf area, as well as carbohydrate levels and starch content across three salinity treatments with and without S. frugiperda. We found that sucrose does not seem to play a role in terms of mediating salinity stress and that the percentage of starch granules found in the rhizomes increases with salinity, for both lineages. Overall, with some minor differences, we found that the native and introduced lineage of $P$. australis are similarly affected by herbivory from $S$. frugiperda, with and without the addition of salinity.
\end{abstract}




\section{ACKNOWLEDGMENTS}

I would like to formally acknowledge Laura Meyerson for her support and guidance throughout my master's study and research as well as for her patience, encouragement, and immense knowledge in the field of invasion biology. I would also like to thank Jose Amador and James Cronin for being on my committee and for their advice and suggestions throughout my manuscript writing. I would like to express my sincere gratitude to the Rhode Island Wild Plant Society and to Hali and Lorrie Beckman, creators of the Carl H. Beckman Fund, for their encouragement and monetary support that allowed me to successfully execute my greenhouse experiment. 


\section{DEDICATION}

I would like to dedicate my thesis to my grandmother, Angela Waidanz. For all the nature walks, helping me keep my feet on the ground, and fueling my love for nature. 


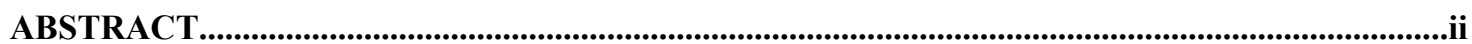

ACKNOWLEDGMENTS.................................................................................................................................ii

DEDICATION........................................................................................................................................................

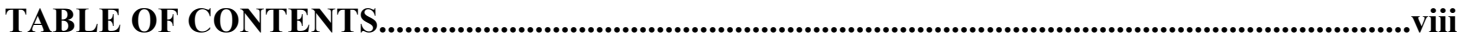

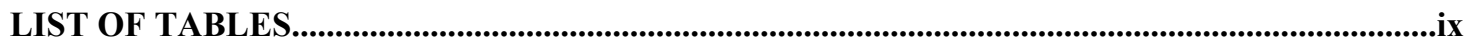

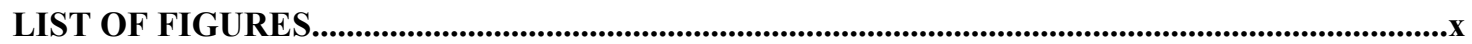

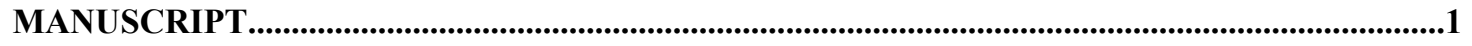

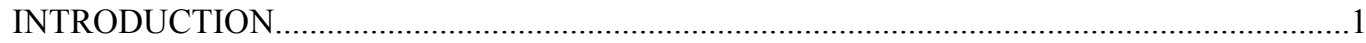

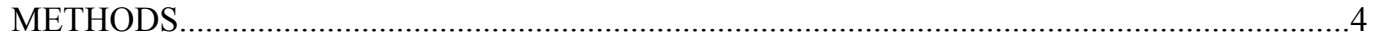

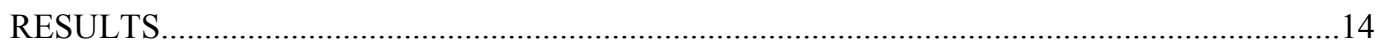

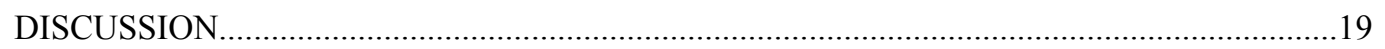

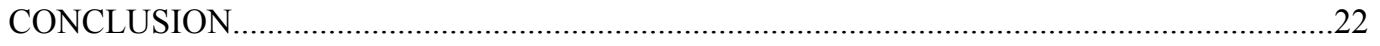

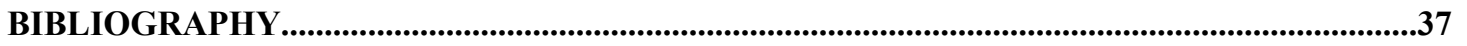




\section{LIST OF TABLES}

TABLE

PAGE

Table 1 | Source information for populations used in this study, where each lineage is represented by five populations.

Table 2 | Number of live replicates for each population in each treatment. Mortalities are recorded in parentheses.

Table 3 | Mean $S$. frugiperda larvae and mean $S$. frugiperda larvae biomass (mg) for each salinity treatment and lineage at the start (initial) and end (final) of the experiment after the FAW were collected............25

Table 4 | Summary of model selection results for the best model for each plant trait measured.............26

Table 5 | Least square means of each plant trait measured for each lineage under each treatment.........27

Table S1a | Correlations among P. australis traits for the North American native lineage....................28

Table S1b | Correlations among P. australis traits for the introduced lineage.....................................29

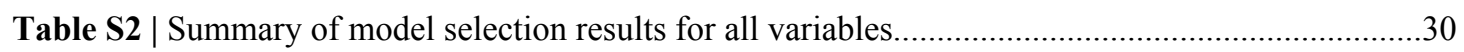




\section{LIST OF FIGURES}

FIGURE

PAGE

Figure 1 | Panels portray a variety of environmental conditions that could impact reed death and the biogeochemistry of the coastlines. .32

Figure 2 | Presence of Spodoptera frugiperda, the fall armyworm, on P. australis. .33

Figure 3 | Experimental design for RI greenhouse study.......................................................................

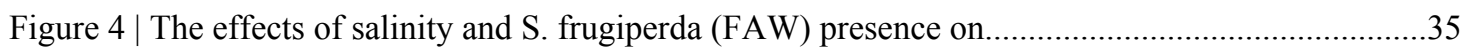

Figure $5 \mid$ The effect of salinity and S. frugiperda (FAW) presence on the rate of change between initial and final samplings for. . .36 


\section{Introduction}

The common reed, Phragmites australis, is a perennial grass that provides a number of ecosystem services such as storm buffering, sediment stabilization, water quality maintenance, and habitat for wildlife (Matoh et al, 1988; Meyerson et al, 2009; Rodriguez and Brisson, 2015 Knight et al, 2018). In North America, this species is composed of three distinct lineages (Saltonstall, 2002; Meyerson et al, 2010): Native, Introduced, and Gulf Coast. North American native, P. australis subsp. americanus (henceforth referred to as native $P$. australis) includes 14 haplotypes endemic to North America and is found throughout much of the US and Canada (Meyerson et al, 2010). Although it has been present in North America for 40,000 years, based on fossil evidence in the southwest (Hansen 1978), it is being rapidly displaced by an introduced lineage, $P$. australis subsp. australis (henceforth called introduced $P$. australis) (Lambert and Casagrande, 2015). After its introduction in the late 19th century, this relatively aggressive lineage quickly dominated the marshes along the Atlantic coast and has since been expanding westward (Meyerson et al, 2010). The third lineage, Gulf Coast $P$. australis subsp. berlandieri (henceforth called Gulf Coast Phragmites), is a coastal type of $P$. australis that grows along the Gulf Coast of the United States as well as South America (Meyerson et al, 2010). While the introduced lineage can be found throughout North America, the native lineage does not appear in the south-eastern region of North America (Saltonstall, 2002). Both the native and introduced lineages have extensively overlapping ranges and, as a result, can be found inhabiting the same marshes in tidal and non-tidal wetlands throughout the United States, although the introduced lineage is far more prevalent (Vasquez et al, 2005; Saltonstall, 2002). By contrast, the Gulf lineage is restricted to the southwestern United States and from the Gulf coast to South America (Chambers et al, 1999; Meyerson et al. 2000; Michinton, 2002; Minchinton and Bertness, 2003; Meyerson et al, 2010; Swearingen and Saltonstall, 2010).

The introduced lineage is thought to have been first introduced to New England salt marshes, based on botanical records (Saltonstall, 2002). To understand how this introduced lineage came to be so "common", we must examine the underlying mechanisms that enabled this genus to tolerate the stressful conditions of its new habitat, such as salinity. In a saline environment, excess salts increase the osmotic 
pressure of the soil, which in turn disrupts normal water and nutrient uptake as well as induce ion imbalances and ionic toxicity (Hatzendorf and Rolletschek, 2001). As a result, P. australis has developed mechanisms such as salt re-translocation/exclusion, tissue dehydration, $\mathrm{K}+$ accumulation, and carbohydrate accumulation to aid in osmotic adjustment (Matoh et al, 1988; Chambers et al, 1998; Hartzendorf and Rolletschek, 2001; Gorai et al, 2010; Albert and Popp, 1977; Matsushita and Matoh, 1991; Lissner and Schierup, 1997; Lissner et al., 1999). While previous studies have focused on salinity tolerance with respect to salt transport and ion balances, few have examined how soluble carbohydrates are affected by salinity, specifically glucose and sucrose, and the possible fitness tradeoffs such a mechanism can impose.

In fresh oligotrophic habitats (Fig. 1a), P. australis produces and utilizes carbohydrates to aid in signaling, resource transportation, stress amelioration, and growth (Matoh et al, 1988; Ashraf and Harris, 2004). Once peak growth is achieved, usually in late summer, these carbohydrates translocate to the rhizomes where they are preserved as insoluble starch granules for subsequent spring growth (Graneli et al, 1992; Ashraf and Harris, 2004; Karunaratne et al, 2004; Konisky and Burdick, 2006). Alternatively, $P$. australis can use these same carbohydrates to ameliorate the impact of stressful environmental conditions. When exposed to saline conditions, these carbohydrates are released into the plant tissues, increasing the osmotic pressure within plant tissues and preventing water loss (Vasquez et al, 2005). In addition, these same hydrolyzed carbohydrates satisfy the requirements for carbohydrate metabolism, which is activated as an additional energy source when plants experience low oxygen conditions (Č́ížková et al, 1996; Ashraf and Harris, 2004; Cha-um et al, 2009). As a result, $P$. australis rhizomes can survive anoxic conditions for several weeks provided they have enough starch reserves and access to air from unobstructed aerenchyma channels in the rhizomes (Č́žková et al. 1996). However, despite the benefits of this carbohydrate reallocation, there is a possible fitness trade-off since this valuable resource is being used for stress alleviation where it would otherwise be reserved for initial spring growth (Armstrong and Armstrong, 1999; Fogli et al., 2002). It has been observed that the occurrence of multiple stressors and their interactions can have a cumulative effect, making tolerable stressors potentially fatal, resulting in a phenomenon known as carbon starvation (Wijte and Gallagher, 1996; Gough and Grace, 1998; Gorai et al, 
2010). Carbon starvation is thought to be a major contributor in the rapid death of vast areas of reed stands, also known as reed-dieback, where rhizomes exhaust their energy reserves in response to two or more combined exogenous stressors and leaving little to no starches to emerge in the spring (Č́ížková et al. 1992).

The phenomenon of carbon starvation has been quantified in European wetlands in Italy and Hungary, where reed die-back has been occurring for decades, most likely the result of combined flooding and eutrophication stress (Tylová et al, 2008; Gigante et al, 2014, Čížková, H. et al, 1992). Carbon starvation has also been linked to the combination of environmental stressors and herbivory from farm animals, little is known about the cumulative impact of environmental stressors and herbivory from insects (Čížková et al, 1992; Renault et al, 2016).

In order to address these concerns, we examined the independent and combined effects of salinity, a common stressor found in salt marshes, and non-native $S$. frugiperda (Figure 2) on the potted reed populations sourced from northeastern North America. While S. frugiperda is found throughout southern North America, this species is regionally invasive to the Northeast and is a known pest for many cereal crops (Canas and O’Neil, 1998). This study examines how the concentration of these carbohydrates in leaves, starches in rhizomes, and plant fitness will change with 1) P. australis lineage; 2) S. frugiperda presence (i.e. herbivory); and 3) increasing salinity (i.e. environmental stress). We hypothesized that: 1) the concentration of carbohydrates, specifically glucose and sucrose will increase with increasing salinity, 2) the presence of starch granules in the rhizomes will decrease with increasing salinity, 3) the amount of soluble carbohydrates will decrease with the presence of herbivory as the sugars are consumed by the plant and insects, 4) plant fitness (i.e. toughness, water content, biomass, etc.) will decrease with increasing salinity, making the plants less resistant to herbivory, and 5) that this impact will vary with lineage, specifically introduced $P$. australis will be more resilient. 


\section{Methods}

\subsection{Source Material}

Two lineages, European haplotype M (introduced) and North American native (native) $P$. australis, were used to examine if and how the effects of salinity and the fall armyworm, S. frugiperda, presence changes with different lineages. Each lineage was represented by five individual populations, each originally sourced from one of ten sites in New England and Maryland (Table 1). Populations were cultivated at the University of Rhode Island's Agronomy Farm facility (41.490872, -71.541703) under stable greenhouse conditions for a minimum of five years to control maternal effects.

\subsection{Preparing Source Material}

On July 8th, 2019 rhizomes were collected from potted $P$. australis populations, cleaned, and cut into segments. Each segment had 5-10 nodes, each with the potential to produce a shoot, to standardize starting material. Once cleaned and cut, rhizomes were stored in labelled bags, wrapped in damp paper towels at $4^{\circ} \mathrm{C}$ until they were planted the following day.

\subsection{Planting Source Material}

Each pre-labelled, 1.9 liter plastic pot was filled $75 \%$ with a wet 1:1 peat (Promix BK-25 V)/sand mixture. To encourage growth, $3.05 \pm 0.07 \mathrm{mg}$ of Nutricoat ${ }^{\circledR}$ was added on top of the soil before the rhizome was added and was covered with additional soil/sand. Once filled, the pots were transferred into the pool with the matching pool number and which were filled with approximately $30 \mathrm{~L}$ of fresh water. The pools in this study were small circular wading pools measuring at $1.14 \mathrm{~m}^{2}$ with a water capacity of $\sim 100 \mathrm{~L}$. The water level was marked using a sharpie to standardize the water depth for all pools. 
The potted rhizomes were watered daily using a sprinkler head on a hose and were supplemented with a $0.1 \%$ Miracle-Gro® Water-Soluble All-Purpose Plant Food (S10385) and 1\% dilution of 20\% $\mathrm{FeSO}_{4}$ iron solution weekly. Water levels of the pools were refilled as needed to the pre-marked water level. Shoots emerged from the rhizomes two weeks after the initial planting and were given two additional weeks to grow until treatments were imposed. Rhizomes that didn't sprout were considered dead and were replaced, if possible, by a spare rhizome of the same population that had sprouted.

\subsection{Experimental Design}

This experiment included three salinity levels (i.e. 0 ppt, 5 ppt, and 15 ppt) and two FAW levels (with and without $S$. frugiperda) which were combined to create six treatments. Treatment was assigned using a random number generator. Each pool contained 101.9 liter pots, one of each population, resulting in a total of 480 pots for the experiment (Figure 3a). Due to high mortality, the number of pools was consolidated from 48 to 42 , and the number of pots dropped from 480 to 357 (Table 2). In the case a population could not evenly be distributed among the treatments, treatments that were predicted to have the highest stress (i.e. high salinity and herbivory) were prioritized over lower stress (i.e. fresh water and no herbivory). Each pool was given a number between 1-42, which was written on the edge of the pool using a sharpie, along with the treatment type the pool was randomly assigned. Treatment type was specified as the salinity level and the presence of $S$. frugiperda larvae.

Each pot was pre labelled with a specific ID which consisted of a pool number (1-42), a population ID, and a replication number (1-7). This ID was written on both sides of the pot and a plastic tag, using a paint pen and industrial sharpie respectively, and etched into a metal tag which was attached to the pot using wiring.

Three additional pools, each representing one of the three salinity treatments, were set aside with 2-3 pots from each population (Table 2). These pots were harvested the same day that the cages were 
introduced to the experimental pools. These "initial" samples were used to standardize the "final" measurements by reporting the change in each response variable.

To create salinity treatments, a stock concentration ( $>70 \mathrm{ppt})$ was made by mixing Instant Ocean sea salt and water in 15 liters of water. Stock solution was added to 19 liter buckets filled with water and stirred until desired salinity level was reached, then was poured into the appropriately labeled pool. Salinity levels were measured daily using a YSI Pro2030 water quality meter to monitor and maintain salinity levels within $2 \%$ of the target (i.e. 4.9-5.1 (low) or 14.9-15.1 (high) ppt). To maintain salinity targets for each treatment, fresh or saltwater was added in $60 \mathrm{~mL}$ increments until the salinity fell within the desired range. To reduce the chance of over-stressing, plants were given a two-week acclimation period to adjust to increase in salinity before the $S$. frugiperda larvae were introduced.

\subsection{Spodoptera frugiperda Larvae}

S. frugiperda larvae were sourced from Benzon Research and arrived as first instars in containers with food media. Due their small size made it difficult to get accurate initial weights. We incubated the larvae at $70^{\circ} \mathrm{C}$ in the containers they came in to encourage growth until they reached the second instar stage, indicated by the color change in the head from black to orange. At which point, we weighed the $S$. frugiperda larvae to collect an initial weight. Each pot that was getting exposed to the S. frugiperda larvae was labeled onto a $1 \mathrm{oz}$ cup and matching lid. Each cup was weighed with the lid and tared before adding six S. frugiperda larvae. S. frugiperda larvae were weighed collectively for initial weight and the initial number of larvae in the cup was recorded. Weighed larvae remained in the labeled cups and stored at $4{ }^{\circ} \mathrm{C}$ until being added to the properly matching pot.

Following the cage experiment, all $S$. frugiperda larvae were collected using forceps and stored in the same labeled cups they were put in for the initial weighing and storage. In most cases, the number of $S$. frugiperda larvae collected was lower than the number originally added to the plant, such missing larvae 
were declared as dead. S. frugiperda larvae were weighed collectively for the final weight, which was recorded along with the number of S. frugiperda larvae that were collected. To account for the fact that some S. frugiperda larvae grew more than others, the final and initial weight was divided by the number of worms present in the cup to get an average weight. Weighed S. frugiperda larvae were kept in the labeled cups and stored at $4^{\circ} \mathrm{C}$ until no longer needed, at which point they were put into a $-20^{\circ} \mathrm{C}$ freezer and euthanized.

\subsection{Cage Design}

Cages were based on the design of Bhattarai et al (2015) (Figure 3b) but modified to cover the whole plant. Caging the whole plant helped to rule out any influence from outside insects. In addition, Grafix (R05DC4025) Clear Dura-Lar, an acetate alternative composed of polyester, was used as the primary material to construct the cages. The flexibility, strength, and clarity of the material made it the ideal choice to construct cages that were lightweight, stable, and didn't impact the availability of light. To meet the size requirements of the cages, the material was ordered with a thickness of $0.13 \mathrm{~mm}$.

Acetate was cut into sheets $0.41 \mathrm{~m}$ by $0.51 \mathrm{~m}$, making the cage $0.51 \mathrm{~m}$ tall with a circumference of $0.38 \mathrm{~m}$. Two circular holes with a diameter of $10.16 \mathrm{~cm}$ were cut diagonally from each other on the sheet so that, when the acetate is rolled, they would appear on opposite sides and opposing ends of the tube. Holes were covered with fine insect mesh attached using a hot glue gun to push glue through the mesh onto the acetate. Gaps were prevented by sealing along the very edge of the holes. The acetate was rolled so that there was a $2.54 \mathrm{~cm}$ overlap, which was hot glued together. The outer and inner flap were sealed shut using additional hot glue. Fine mesh was placed over the top opening and attached to the acetate using a hot glue gun to push the glue through the mesh and onto the acetate. Two marking flags were glued onto the outside of the cage on opposing sides with $15.24 \mathrm{~cm}$ of wire hanging off the bottom. This wire was stuck into the soil until they reached the bottom of the pot and until the bottom $2.54 \mathrm{~cm}$ of the acetate cage was covered with soil, to prevent any immigration or emigration of insects. This wire helped to stabilize the cage to the 
pot, reducing the effect of wind which could blow the cages off the plants. To maintain optimal temperatures, the sides of the greenhouse were rolled up to prevent overheating, and subsequently overstressing, the plants.

\subsection{Greenhouse Experiment}

On August 14, 2019, 37 days after the initial planting, the pools were emptied, cleaned, and filled with either fresh (0 ppt), low salt (5 ppt), or high salt (15 ppt) water. After two weeks of acclimation, acetate cages were placed on all pots in the experimental pools and pots from the control pools were harvested. S. frugiperda larvae were added and kept on the plants for 10 days before being collected and weighed for final biomass. On Sept 12,2019, the cages and S. frugiperda larvae were removed. Plants were harvested over the course of the following three days.

\subsection{Sample Collection}

From each pot, a total of six leaves were collected, starting from the top of the tallest stem going down. If all leaves are collected from the tallest stem, including the newest unfurled leaf at the very top, then leaves will be collected from the second tallest stem from the top down. The top-most unfurled leaf of the tallest stem was measured for toughness, photographed for specific leaf area (SLA), and collected leaf water content (LWC) (Bhattarai et al, 2015). The three leaves below the top-most unfurled leaf, on the same stem, were collected and photographed to determine leaf damage or leaf consumption. Once photographed, the same three leaves, plus two additional leaves were wrapped in aluminum foil, labelled with the pool number and population name, then flash frozen in liquid nitrogen. Leaf samples were stored at -80 until subsequent carbohydrate analysis. 
Following the leaf collection, all aboveground biomass was collected 1-2 $\mathrm{cm}$ above the soil and stored in labeled paper bags. Pots were emptied and below ground biomass was rinsed with fresh water. A subsample of belowground tissue, including 1 or 2 stem bases and a full internode to the left and right of that stem base, was cut for histological analysis. Both the subsample and the rest of the belowground biomass were immediately wrapped in aluminum foil, labeled with the pool number and population name, and flash frozen in liquid N. Samples were stored on dry ice before being stored at $-80^{\circ} \mathrm{C}$ in the lab until sample processing.

\subsection{Leaf Damage}

Three leaves were collected and photographed using a scale to determine how much of the leaf tissue was consumed by herbivory, or leaf damage. Leaf width, length, and area were measured using ImageJ $(1.47 \mathrm{v})$. Leaf width and length are represented by the widest part of the leaf and the distance from the tip of the leaf to the ligule, respectively. In the event these areas were affected by the tissue consumption from S. frugiperda larvae, we used the surrounding tissue to predict where the edges would have been, estimating from said estimated edge. Leaf area was represented by two measurements, predicted leaf area and observed leaf area. Both areas were determined by tracing along the perimeter of the leaf and creating a polygon. The predicted area, or pre-damaged leaf area, estimated the total leaf area by including the areas that have been chewed as well as the remaining tissue. The observed area, however, only measured the area of the remaining tissue. Once measured, the amount consumed was determined by subtracting the observed area from the predicted area, to get the area consumed. This was divided by the predicted area to get percent area consumed.

\subsection{Percent Starch}

Dead rhizome tissue was separated from living rhizome tissue based on color and appearance.

Rhizomes that were dark brown and spongy were grouped as dead whereas tissue that was beige to white 
and was stiff was considered healthy. Most, if not all, pots had rhizome tissue that was white, indicating new rhizome growth. If present, cross sections were made from both the white and beige colored tissue, in order to account for the fact that the newest rhizomes don't hold as much starch as the older rhizomes (Karunaratne et al, 2004). Starch measurements were averaged between these rhizomes.

Three cross sections were cut from at least two live internodes from each rhizome sample to examine for starches. These cross-sections were stained with Gram's iodine and examined under the Zeiss microscope (Armstrong \& Armstrong, 1999; Fogli et al, 2002; Reale et al, 2012). Cross sections were photographed and saved with the appropriate sample ID until starch reserves (\% cover) were quantified using ImageJ $(1.47 \mathrm{v})$ (Reale et al, 2012). In the event that cross sections from the two internodes differed within the rhizome, a cross section from each was measured and the percentage starch results were averaged. If new rhizome tissue was being analyzed in addition to the more mature rhizome, the measurements between the two were averaged to account for the variability of the rhizome with age (Karunaratne et al, 2004).

\subsection{Aboveground Biomass}

Bagged biomass was weighed for wet weight before being dried. Samples were placed into the drying oven at $60^{\circ} \mathrm{C}$ for two weeks to ensure that samples are thoroughly dried. Samples were transferred from the oven to the scale using a desiccator to collect final weights. The bag weight was subsequently subtracted from the final weight to get the dried weight for the tissue only.

\subsection{Specific Leaf Area}

Specific leaf area (SLA) was calculated using the area and the dry weight of the top-most unfurled leaf. After the leaf sample was collected and photographed as described in Sample Collection, the leaf was 
weighed for a wet weight and placed into a labeled paper bag. Leaves were left in the dryer oven set at $70^{\circ} \mathrm{C}$ for a week before being weighed for dry weight. Area of the leaf was determined using ImageJ $(1.47 \mathrm{v})$, by tracing along the perimeter of the leaf and creating a polygon. This value was later divided by the dry weight of the same leaf described in the following equation (Leaf area/dry weight).

\subsection{Leaf Toughness}

Leaf toughness was measured using a penetrometer (Itin Scale Company, Brooklyn, New York, USA), which measures the amount of force (in lbs.) required to puncture the leaf tissue using a blunt steel rod (4.8 $\mathrm{mm}$ in diameter) (Salgado and Pennings, 2005), on the top-most completely unfurled leaf on the tallest stem (Bhattarai et al., 2015).

\subsection{Leaf Water Content}

After being measured for SLA and toughness, the same leaf was placed into a labeled paper bag, weighed, dried at $70^{\circ} \mathrm{C}$ for a week, then reweighed to get dry weight. Water content was calculated using the wet and dry weight in the equations (wet weight - dry weight)/dry weight).

\subsection{Carbohydrates - Glucose and Sucrose}

Flash frozen leaf tissue was put into a mortar with liquid nitrogen and ground into a fine powder (Raessler, 2011; Steinbachová-Vojtíšková et al, 2006; Koppitz 2004; Woitke et al, 1997; Č́žǩková, et al. 1996). Ground sample was weighed into $2 \mathrm{ml}$ microcentrifuge tubes to standardize the starting tissue. In the case the sample was too small, all the tissue was ground. 
Soluble carbohydrates were extracted and analyzed using the Glucose (HK) assay kit (Sigma Aldrich, St. Louis, MO) and following the protocol designed by Zhao et al (2010). Approximately 130 ( \pm 10) $\mathrm{mg}$ of ground sample was added to a test tube with $2 \mathrm{~mL} 80 \%(\mathrm{v} / \mathrm{v})$ ethanol, which is used to extract the soluble carbohydrates from the tissue. The test tubes were incubated on a heat block set at $80-85^{\circ} \mathrm{C}$ for 5 min then centrifuged at 3,000 g for $10 \mathrm{~min}$ (Koppitz et al, 2004b; Tang et al, 2014; Woitke et al, 1997). Supernatant was decanted into another tube and additional $2 \mathrm{~mL}$ of $80 \%(\mathrm{v} / \mathrm{v})$ ethanol was added. In total, the powdered sample was extracted for soluble sugars three times (Koppitz et al, 2004b). All three supernatants were combined into one $6 \mathrm{~mL}$ sample (Campbell et al, 1999). Approximately $60 \mathrm{mg}$ of finely ground charcoal was added to each sample and mixed briefly by hand to remove any color from the supernatant, which could skew the microplate results (Zhao et al, 2010). They sat for 5 mins and then were centrifuged at 3,000 $\mathrm{g}$ for 15 mins to make the extract clear.

Before the addition of the standards, three $20-\mu \mathrm{L}$ aliquots of sugar extracted from each sample were added to separate wells of a 96-well microplate and dried in an oven at $50^{\circ} \mathrm{C}$ for 30 min to remove ethanol from sample wells and bring wells to dryness. Samples were then resuspended in $20 \mathrm{uL}$ of DI water for micro-plating. Soluble carbohydrate micro-plating was conducted using the combined protocols from Campbell et al (1999) and Hendrix (1993). Each assay was measured against a series of glucose standards $(0.0,0.1,0.25,0.35,0.5,0.75,1.0 \mathrm{mg} / \mathrm{mL})$. In addition to representing zero in the standards, three empty wells served as additional blanks. All standards and water were triplicated and averaged to form a linear relationship between concentration and absorbance.

Samples were processed to measure the concentration of glucose first by adding $100 \mathrm{uL}$ of the reagent mixture to each well on the microplate. The plates were covered with a plate cover to prevent evaporation and incubated in an oven at $37^{\circ} \mathrm{C}$ for $15 \mathrm{~min}$. The reagent mixture only produces a color with D-glucose-6-phosphate. As a result, the assay will only detect the ethanol-extracted glucose in the samples that will be converted to glucose-6-phosphate by the hexo-kinase in the reaction mixture. This was read on a Synergy ${ }^{\text {TM }}$ HTX Multi-Mode Microplate Reader at $340 \mathrm{~nm}$. 
To analyze for sucrose, $83 \mathrm{EU}$ invertase (EC 3.2.1.26) was added to each well containing phosphoglucose isomerase, reincubate, and reread at $340 \mathrm{~nm}$. The absorbance was proportional to the sucrose plus the glucose in each well, from which the amount of sucrose in each sample could be determined. Invertase solution was prepared by adding $50 \mathrm{mg}$ of powdered invertase preparation to $5 \mathrm{~mL}$ $0.1 \mathrm{M}$ citrate buffer ( $\mathrm{pH} 6.0)$.

To determine the concentrations of the unknowns, glucose standards were used to construct a linear relationship between absorbance and concentration $\left(\mathrm{R}^{2}\right.$ should be $\left.>.98\right)$. Sucrose concentration in samples will be calculated according to the glucose concentration (proxy for sucrose concentration) - initial glucose measurement and then multiplied by 0.96 to account for water loss when glucose and fructose units are hydrolyzed.

\subsection{Statistical Methods}

Correlation tables were made for each lineage comparing the response variables (Table S1a and S1b). We used separate generalized linear mixed models (GLMM) to test whether carbohydrates, starch, aboveground biomass, specific leaf area, leaf toughness, leaf water content, and leaf damage for $P$. australis varied with herbivory, salinity level $(0,5,15 \mathrm{ppt})$, and $P$. australis lineage. $P$. australis population and pool number were included in the models as random effects to account for any within-lineage variation and any variation from pool position within the greenhouse Quantile-quantile (QQ) plots and residual plots were used to determine potential outliers. No outliers were removed from the dataset. All data was analyzed using R (version 3.6.2) (R Core Team, Vienna, Austria).

Candidate models were constructed using all possible variations of independent variables (i.e. salinity, herbivory, lineage). The number of possible combinations was restricted to meet the following parameters: 1) random effects were included for all models, 2) Interaction terms were only present in the model if their corresponding main effects were also present in the model. I used Akaike's Information 
Criteria to select the most informative model for each of the 9 dependent variables being tested. Candidate models that had a $\triangle \mathrm{AIC}$ value $\left(=\mathrm{AIC}_{\mathrm{i}}-\mathrm{AIC}_{\text {min }}\right) \leq 2$ were considered (Meyerson et al, unpub), ranked by AIC values from lowest to highest. The AIC weights reported indicate the weight of evidence in favor of each model being the best model given the set of candidate models. Goodness of fit of the best model is represented by two values: the marginal $\mathrm{R}^{2}$ (or $\mathrm{R}^{2}$-fixed) which represents the variance explained by the fixed effects combined and the conditional $\mathrm{R}^{2}$ (or $\mathrm{R}^{2}$-model) which represents the variance explained by all the fixed and random effects combined. Least square means and corresponding standard errors for each plant trait under each treatment condition were derived using the model that included the effects of $S$. frugiperda herbivory, salinity, and lineage as well as their interactions.

\section{Results}

\subsection{Impact of Salinity on Carbohydrates and Starch Reserves}

Salinity had a weak effect on the levels of glucose for both the introduced and the native lineages (Figure 4a). In comparison to the freshwater treatment, glucose in the native lineage increased by $27.42 \%$ and $27.48 \%$ (n.s.), while the introduced lineage increased by $32.30 \%$ and $41.49 \%$ (n.s.) for the low and high saline conditions, respectively. For native and introduced lineages, glucose levels increased by $27.42 \%$ and $32.3 \%$ respectively when exposed to the low salinity (5 ppt) treatment (Table 5). However, when exposed to the high salinity (15 ppt) treatment the glucose levels plateaued for the native lineage while glucose increased an additional 6.95\% for the introduced lineage (Table 5). Generally, the introduced lineage had more glucose (Figure 4a) and had the largest change in glucose (Figure 5a) (n.s.), the major exception being salinity treatment 0 ppt, where glucose was the lowest for both lineages (n.s.). Sucrose, however, was not as affected by salinity which remained stagnant with increasing salinity for both lineages, indicating that salinity has little influence on the amount of sucrose in the aboveground biomass of both lineages (Figure $4 b$ ) (n.s.). While the introduced lineage had higher levels of sucrose for all salinities, 
relative to the native lineage, the native lineage had the largest change in sucrose when there was no salinity and the smallest change when grown in low salinity (Figure 5b).

Regardless of lineage, percent starch was heavily impacted by salinity where starch increased with increasing salinity (Figure 4c). The largest increase in starch occurred between the no salinity and high salinity treatments, where the native lineage increased by $72.86 \%$ and the introduced lineage increased by 94\% $(\mathrm{p}<0.05)($ Table 5). When compared to the initial measurements taken (Figure 5c), the change in starch decreased with increasing salinity for the native lineage. The introduced lineage followed a similar trend, however, the change in percent starch spiked by $64.84 \%$ when the plants were exposed to the low salinity treatment.

\subsection{Impact of Herbivory and Salinity on Carbohydrates and Starch Reserves}

When the salinity treatments were paired with herbivory, glucose levels for both lineages mirrored the glucose levels of the treatments without herbivory (Figure 4a). When only herbivory was affecting the plants, glucose levels were at their highest and sucrose levels were at the lowest for both the native $(4.538 \pm$ 0.373 , n.s.; $4.719 \pm 0.225, \mathrm{p}<0.05)$ and introduced $(4.838 \pm 0.367$, n.s.: $4.799 \pm 0.219$, n.s. $)$ lineage

(Figure 4a-b,Table 5). With the addition of salinity, glucose in the leaf tissue of the native lineage dropped by $28.82 \%$ and $20.45 \%$ while the levels in the introduced leaf tissue dropped by $33.01 \%$ and $22.08 \%$ for the low and high salinity treatments respectively (Table 5). Although it appears that glucose levels for both lineages followed a similar pattern, the change from initials measurements (Figure 5a) indicate that the introduced lineage, both with and without $S$. frugiperda, had the highest increase in glucose concentrations relative to the native for both salinities (n.s.). Although salinity alone had little effect on sucrose levels, the interaction of herbivory and high salinity revealed an overall increasing trend in sucrose concentrations with increasing salinity. When exposed to both high salinity and herbivory the sucrose levels for the native and introduced lineage significantly increased by $21.28 \%$ and $17.52 \%$, respectively (Figure $4 b$ ). 
Treatments with herbivory had a smallest (n.s.) change in glucose and a slightly larger change in sucrose (n.s.) relative to the treatments without herbivory, for all salinity treatments and both lineages (Figure 5a-b) Examining the change in sucrose from the initial to the final measurements, the introduced lineage had a steady increase with increasing salinity for both treatments with and without S. frugiperda (Figure 5b). The native lineage, however, had a high increase in sucrose, with and without S. frugiperda, when grown in the freshwater and high salinity treatment. For both lineages, sucrose levels were higher in plants that were exposed to herbivory, and with the exception of the low salinity treatment, the native lineage had the highest sucrose increase over the course of the experiment.

Percent starch was higher in plants, both from introduced and native lineages, that were exposed to herbivory relative to those that were not (Figure 4c). With the introduction of salinity, plants without $S$. frugiperda had a higher percent starch value and overall percent starch increased for both treatments and both lineages. Although the introduced lineage without $S$. frugiperda had statistically higher levels of starch in saline conditions relative to the S. frugiperda treatment, this can be attributed to the small variances (Table 5). The native lineage followed a very similar pattern to the introduced, where the no-S. frugiperda treatment had higher percent starch values for both saline conditions relative to the $S$. frugiperda treatment, however, these were not considered to be significantly different. Overall, both lineages followed a similar pattern which was heavily influenced by salinity regardless of the presence of $S$. frugiperda. While herbivory has a weak effect on the presence of starches in rhizomes, the presence of starches is heavily impacted by salinity (Figure 5).

\subsection{Impact of Salinity on Plant Fitness}

For both lineages, salinity had a larger impact on the production of aboveground biomass than herbivory (Figure 4d), where the production of aboveground biomass decreased with increasing salinity (Table 5). With the exception of the freshwater treatment (i.e. 0 ppt), the introduced lineage produced 
$26.5 \%$ and $22.5 \%$ more aboveground biomass than the native lineage for the low and high salinity

treatment (Table 5). The rate of biomass production slightly decreased with increasing salinity, with a lot of variation in the native lineage (Figure $5 \mathrm{~d}$ ).

Specific leaf area and the rate of change for specific leaf area was larger for the treatment without S. frugiperda, with no clear difference between lineages (Figure 4e). With the exception of the introduced lineage without $S$. frugiperda, there was no change in specific leaf area with increasing salinity (Table 5). While there was no difference in SLA between the freshwater and low salinity treatments (n.s.) for the introduced lineage, SLA sharply decreased by $7.53 \%$ when salinity increased from low to high (n.s.). In addition to specific leaf area, there was no statistical difference between treatments for each lineage with leaf toughness (Figure 4g). Although, visually, the native lineage had the highest toughness, the introduced lineage had the largest increase over the course of the experiment. For both lineages, leaf water content and the rate of change for leaf water content increased with increasing salinity (Figure $4 f$, Figure $5 f$ ). The native lineage overall had on average less water in the leaves relative to the introduced lineage for all salinities.

\subsection{Impact of Herbivory on Plant Fitness}

With a couple exceptions, overall herbivory did not significantly affect aboveground biomass specific leaf area, leaf water content, or leaf toughness for either lineage (Table 5 and 6). Plants, from both lineages, that were exposed to herbivory generally had lower specific leaf area values than the no- $S$. frugiperda treatment (Figure 4e). Leaf toughness followed a similar pattern, although there was more overlap (Figure 4g). With the addition of S. frugiperda, the percent water in the leaves increased, especially for the native lineage (Figure 4f). Relative to the no-S. frugiperda treatment, the leaf water content for the native and introduced lineages with S. frugiperda followed a similar pattern to the introduced lineage without S. frugiperda. Indicating that herbivory had a drastic change on leaf water content for the native lineage but little to no impact on the introduced lineage. The rate of change for each of these plant traits also revealed similar patterns to the plots in Figure 4. 


\subsection{Impact of Lineage Origin}

Overall, lineage did not influence the amount of glucose or sucrose found in the aboveground biomass and did not affect the amount of starch found in the rhizomes for any of the treatments, when standardized by the amount of tissue processed (Figure 4a, 4b, 4c). The introduced lineage is prone to more aboveground biomass growth relative to the native lineage, regardless of salinity and herbivory (Figure 4d). In addition, the introduced lineage had a higher percentage of leaf water content for all salinity treatments and higher specific leaf area values for all but the highest salinity treatment (Figure 4e, 4f). As mentioned before, the leaf water content for the native lineage was impacted more by the presence of herbivory relative to the introduced lineage, which revealed little change in leaf water content (Figure 4f). In addition, there was a higher percentage of damage on the leaves of the native lineage than the introduced (Table 5), indicating that the presence of S. frugiperda herbivory has a greater impact on the native lineage than the introduced lineage.

\subsection{Spodoptera frugiperda Biomass and Survival}

Although there was more leaf damage found on the native lineage, the average $S$. frugiperda biomass was lower relative to the introduced lineage (n.s.) (Figure 4i). This discrepancy can be attributed to the average number of $S$. frugiperda, which was significantly greater on the native lineage than it was on the introduced lineage (Figure $4 \mathrm{j}$ ), especially with increasing salinity. Not only did the average number of S. frugiperda decrease on the introduced plants, it slightly increased on the native lineage.

Unsurprisingly, plants exposed to herbivory, regardless of lineage, had a higher percentage of leaf damage than the no-S. frugiperda treatment. However, the native lineage leaf tissue was consumed $44.42 \%$, $85.37 \%$, and $25.84 \%$ more than the introduced lineage for salinities $0(\mathrm{p}<0.05), 5(\mathrm{p}<0.05)$, and $15 \mathrm{ppt}(\mathrm{p}$ $<0.05$ ), respectively (Figure $4 \mathrm{~h}$, Table 5). In addition, the biomass and number of the S. frugiperda larvae 
on the introduced lineage decreased steadily with increasing salinity (n.s., n.s.), following an inverse relationship relative to sucrose (Figure 4, Table 5).

\section{Discussion}

While cages prevented the interference of outside insects, they were not present until the start of the experiment. As a result, the plants were exposed and damaged by outside pests (i.e. aphids and $S$. frugiperda) during the growing period, despite the application of safer soap as a preventative. Fortunately, after comparing the leaf damage or leaf consumption for the treatments with and without $S$. frugiperda, we found that these outside pests had no significant influence on the results, as indicated by the little amount that was consumed relative to the plants exposed to the $S$. frugiperda (Figure 4h, Table 5). Overall, we found that for the introduced lineage, consumption decreased when plants were grown in saline conditions (n.s.).

Our study revealed that while the presence of one stressor (i.e. herbivory or salinity) increased glucose levels, the presence of both did not increase glucose. Since glucose increased with salinity, it is clear to say herbivory caused glucose to drop. However, whether this is due to herbivory from S. frugiperda specifically or simply general wounding is unknown. To properly separate the two, a supplemental study should be conducted where a subset of plants from each lineage (from one location in New England) is sampled each week over the course of several weeks to gather longitudinal data on the change of glucose. Halfway through the experiment, half of these plants should be exposed to herbivory by $S$. frugiperda, while the other half is exposed to wounding by tearing the leaves and harvested the same as before. This experiment should map out how glucose increases with salinity and how it changes the moment herbivory is added.

Meanwhile, in accordance with previous studies, sucrose accumulation was not of importance for either lineage with regards to any of the salinity treatments (Hartzendorf and Rolletschek, 2001). For $P$. australis, soluble carbohydrates have been known to increase with increasing salinity in an attempt to 
modulate osmotic pressure (Matoh et al, 1988; Chambers et al, 1998; Hartzendorf and Rolletschek, 2001; Gorai et al, 2010; Albert and Popp, 1977; Matsushita and Matoh, 1991; Lissner and Schierup, 1997; Lissner et al., 1999). According to our models for glucose and sucrose the interaction of herbivory and salinity was a major driving force in the presence of carbohydrates (Table 4), partially supporting our first hypothesis. Without herbivory, glucose increased, as expected, but sucrose did not follow this pattern further supporting the conclusion that sucrose is not an important factor with salinity stress.

Although the aboveground biomass for both lineages decreased with increasing salinity, the introduced lineage, overall, produced more aboveground biomass on average regardless of salinity relative to the native lineage. This is not unexpected given the results of previous studies which have concluded that the introduced lineage is more tolerant of saline conditions than the native lineage (Achenbach and Brix, 2014; Meyerson et al, 2020). Specific leaf area was higher for the treatments without herbivory, which is to be expected since tissue consumption should decrease the area of the leaf which would decrease the SLA. This did not differ with lineage or salinity conditions.

Interestingly, the native lineage appeared to have tougher leaves than the introduced lineage, until salinity increased in which leaf toughness decreased. This could be explained by the leaf water content. Examining the correlation tables, there is an inverse relationship between toughness and leaf water content $\left(r^{2}=-0.34, p<0.001\right)$. As salinity increased, the leaf water content increased which decreased the leaf toughness. Unsurprisingly, toughness decreased with herbivory as a result of the holes in the leaf tissue from consumption.

While both lineages are found in salt marshes, the introduced lineage has been described as having a broader salinity range relative to the native lineage, allowing it to thrive in areas where the native lineage is struggling (Price et al, 2013). Although the introduced lineage measured higher in some plant traits relative to the native lineage, lineage itself was not a major component in the models (Table 4), indicating that salinity and herbivory affect these lineages similarly. However, it is important to note that while $S$. frugiperda biomass and numbers didn't differ too much between lineages, the native lineage was associated 
with a higher percent leaf damage. This has been observed in other studies as well, indicating the possibility that other leaf chewing insects in addition to $S$. frugiperda may benefit off native $P$. australis as well (Bhattarai et al, 2017). The native lineage has been associated with increased nitrogen uptake with increasing salinity, more so than the introduced lineage, making them more desirable to herbivorous insects (Mozder et al, 2010; Croy et al, 2020. However, it is unknown whether S. frugiperda prefers the native lineage to the introduced with varying salinities, a concept that should be explored in further detail. When checking for correlations, there was a weak but significant negative relationship between the amount of sucrose in the aboveground biomass and the average biomass of the $S$. frugiperda feeding on said aboveground biomass (Table S1b). This relationship was only present for the introduced lineage (Table S1a). 


\section{Conclusions}

Re-evaluating my hypotheses, it is clear that $S$. frugiperda did not benefit from the presence of salinity since the biomass of $S$. frugiperda did not increase across salinity treatments. Although, these results reveal that the introduced lineage could have a competitive advantage, where stands growing in salt water will experience less herbivory while native stands will be consumed regardless of salinity. Unexpectedly, salinity increased the amount of starch granules stored in the rhizomes. Based on the literature, we predicted that the presence of salinity would encourage the starch to dissolve, but it had the opposite effect, turning water soluble sugars into a solid form. Thus, we can reject the hypothesis that herbivores benefit from the presence of salinity stress, at least for $S$. frugiperda. While there was a decrease in the glucose levels when salinity and $S$. frugiperda were affecting the plants, when only $S$. frugiperda were affecting the plants glucose increased. Similarly, when the plants were only exposed to the saline conditions, glucose increased. It was only when the two were paired together that glucose remained low. On the other hand, the presence of S. frugiperda was associated with an increase in sucrose with high salinity and herbivory, otherwise sucrose showed little change. While there is still some merit to the fact that the presence of $S$. frugiperda decreases sugars, there does not seem to be a clear pattern that explains the results for all three salinity scenarios with and without S. frugiperda. Finally, we can reject the final hypothesis that the introduced lineage will be the most likely to outcompete the native given the circumstances. However, based on the models and plots, lineage had little to no effect on the results. Indicating that while intrusive, the introduced and native varieties are more alike, based on their reactions to stressors, than they are different. 
Table 1 | Source information for populations used in this study, where each lineage is represented by five populations.

\begin{tabular}{|c|c|c|c|c|c|c|c|c|}
\hline \multirow[t]{2}{*}{ Lineage } & \multirow[t]{2}{*}{ Pop. ID } & \multirow[t]{2}{*}{ Latitude } & \multirow[t]{2}{*}{ Longitude } & \multirow[t]{2}{*}{ State } & \multicolumn{3}{|c|}{ Replicates } & \multirow[t]{2}{*}{ Location } \\
\hline & & & & & Potted & Initial & Final & \\
\hline \multirow[t]{5}{*}{ Native } & $\mathrm{RCN}$ & $43.315988^{\circ}$ & $-70.566463^{\circ}$ & ME & 48 & 40 & 40 & Rachel Carson Wildlife Refuge \\
\hline & GBN & $43.053978^{\circ}$ & $-70.895450^{\circ}$ & NH & 66 & 52 & 52 & Great Bay, Stratham \\
\hline & FPN & $41.589^{\circ}$ & $-70.637^{\circ}$ & MA & 60 & 42 & 41 & Falmouth, Great Sippewissett Marsh \\
\hline & JPN & $41.71345^{\circ}$ & $-71.28647^{\circ}$ & RI & 50 & 35 & 35 & Jacob's Point \\
\hline & MD 1 & $38.77339^{\circ}$ & $-75.97547^{\circ}$ & MD & 64 & 38 & 37 & Choptank River \\
\hline \multirow[t]{5}{*}{ Introduced } & WebM & $43.29803^{\circ}$ & $-70.57923^{\circ}$ & ME & 80 & 46 & 43 & Webhannet \\
\hline & GBM & $43.053978^{\circ}$ & $-70.895450^{\circ}$ & NH & 53 & 45 & 45 & Great Bay, Stratham \\
\hline & FPM & $41.586469^{\circ}$ & $-70.636438^{\circ}$ & MA & 60 & 49 & 49 & Falmouth, Great Sippewissett Marsh \\
\hline & $\mathrm{BICM}$ & $41.179092^{\circ}$ & $-71.567848^{\circ}$ & RI & 70 & 45 & 45 & Block Island Conservatory \\
\hline & MD 2 & $38.773714^{\circ}$ & $-75.976^{\circ}$ & MD & 51 & 28 & 28 & Choptank River \\
\hline
\end{tabular}


Table 2 | Number of live replicates for each population in each treatment. Mortalities are recorded in parentheses. Initial samples are label with the treatment number I0, I5, or I15 depending on salinity. There was no herbivory on these plants

\begin{tabular}{|c|c|c|c|c|c|c|c|c|c|c|c|c|c|c|}
\hline \multirow{2}{*}{\multicolumn{3}{|c|}{$\begin{array}{l}\text { Treatment Salinity } S \text {. frugiperda } \\
\text { Number }\end{array}$}} & \multicolumn{6}{|c|}{ Native } & \multicolumn{6}{|c|}{ Introduced } \\
\hline & & & RCN & GBN & FPN & JPN & MD 1 & Total & WebM & GBM & FPM & BICM & MD 2 & Total \\
\hline I0 & 0 & NA & 2 & 3 & 2 & 2 & $1(1)$ & 11 & 2 & 2 & 2 & 2 & 1 & 9 \\
\hline I5 & 5 & NA & 2 & 4 & 2 & 2 & 2 & 12 & 2 & 2 & 3 & 2 & 1 & 10 \\
\hline I15 & 15 & NA & 2 & 3 & 2 & 2 & 2 & 11 & 2 & 2 & 3 & 2 & 1 & 10 \\
\hline 1 & 0 & No & 5 & 7 & 6 & 5 & 5 & 28 & 7 & 6 & 7 & 6 & 4 & 30 \\
\hline 2 & 0 & Yes & 5 & 7 & 6 & 5 & 5 & 28 & 7 & 7 & 7 & 6 & 4 & 31 \\
\hline 3 & 5 & No & 6 & 7 & 6 & 5 & 5 & 29 & $5(2)$ & 6 & 7 & 7 & 4 & 31 \\
\hline 4 & 5 & Yes & 6 & 7 & 6 & 4 & 6 & 29 & $5(1)$ & 6 & 7 & 7 & 4 & 30 \\
\hline 5 & 15 & No & 6 & 7 & $5(1)$ & 5 & 5 & 29 & 7 & 7 & 6 & 6 & 4 & 30 \\
\hline 6 & 15 & Yes & 6 & 7 & 6 & 5 & 6 & 30 & 6 & 7 & 7 & 7 & 5 & 32 \\
\hline
\end{tabular}


Table 3 | Mean S. frugiperda larvae and mean S. frugiperda larvae biomass (mg) for each salinity treatment and lineage at the start (initial) and end (final) of the experiment after the FAW were collected.

Significance $(\mathrm{p}<0.05)$, determined using Kruskal-Wallis analysis, is represented by letters.

\begin{tabular}{|c|c|c|c|c|c|}
\hline \multirow[t]{2}{*}{ Variable } & \multirow{2}{*}{$\begin{array}{c}\text { Salinity } \\
\text { (ppt) }\end{array}$} & \multicolumn{2}{|c|}{ Native } & \multicolumn{2}{|c|}{ Introduced } \\
\hline & & Initial & Final & Initial & Final \\
\hline \multirow{3}{*}{$\begin{array}{l}\text { Mean \# } \\
\text { S. frugiperda } \\
\quad \text { larvae }\end{array}$} & 0 & $6.00 \pm 0.00 \mathrm{a}$ & $1.50 \pm 0.24 \mathrm{ab}$ & $6.00 \pm 0.00 \mathrm{a}$ & $1.23 \pm 0.22 \mathrm{a}$ \\
\hline & 5 & $6.00 \pm 0.00 \mathrm{a}$ & $1.03 \pm 0.25 \mathrm{~b}$ & $6.00 \pm 0.00 \mathrm{a}$ & $1.17 \pm 0.24 \mathrm{a}$ \\
\hline & 15 & $6.00 \pm 0.00 \mathrm{a}$ & $1.63 \pm 0.25 \mathrm{a}$ & $6.00 \pm 0.00 \mathrm{a}$ & $0.97 \pm 0.16 \mathrm{a}$ \\
\hline Mean & 0 & $0.001 \pm 0.00 \mathrm{a}$ & $0.038 \pm 0.014 \mathrm{a}$ & $0.001 \pm 0.00 \mathrm{a}$ & $0.046 \pm 0.010 \mathrm{a}$ \\
\hline S. frugiperda & 5 & $0.001 \pm 0.00 \mathrm{a}$ & $0.016 \pm 0.009 \mathrm{a}$ & $0.001 \pm 0.00 \mathrm{a}$ & $0.026 \pm 0.010 \mathrm{ab}$ \\
\hline $\begin{array}{c}\text { Biomass } \\
(\mathrm{mg})\end{array}$ & 15 & $0.001 \pm 0.00 \mathrm{a}$ & $0.019 \pm 0.007 \mathrm{a}$ & $0.001 \pm 0.00 \mathrm{a}$ & $0.011 \pm 0.005 \mathrm{~b}$ \\
\hline
\end{tabular}


Table 4 | Summary of model selection results for the best model for each plant trait measured. Best model is the model with the smallest AIC value. In the case of ties, the better model is the one with the fewest parameters. F = S. frugiperda presence (yes, no), $\mathrm{S}=$ salinity treatment $(0,5,15 \mathrm{ppt})$. Goodness of fit statistics are represented by $\mathrm{R}^{2}$-fixed, or marginal $\mathrm{R}^{2}$, and $\mathrm{R}^{2}$-model, or conditional $\mathrm{R}^{2}$.

\begin{tabular}{|c|c|c|c|c|c|c|}
\hline & Response Variable & AIC-Best Model & AIC & Akaike Wt. & $\mathbf{R}^{2}$-fixed & $\mathbf{R}^{2}$-model \\
\hline \multirow[t]{5}{*}{ Initial } & $\begin{array}{c}\text { Glucose } \\
\text { (mg g-1 dry wt) }\end{array}$ & $\mathrm{S} * \mathrm{~L}+\mathrm{S}+\mathrm{L}$ & 638.7 & 1 & 0.000 & 0.413 \\
\hline & $\begin{array}{c}\text { Sucrose } \\
\left(\mathrm{mg} \mathrm{g}^{-1} \text { dry wt) }\right.\end{array}$ & $\mathrm{S}$ & 637.5 & 0.461 & 0.044 & 0.171 \\
\hline & Starch (\%) & $S * L+S+L$ & 377.7 & 0.492 & 0.368 & 0.368 \\
\hline & $\begin{array}{l}\text { Aboveground } \\
\text { Biomass (g) }\end{array}$ & Intercept & 175.2 & 0.507 & 0.000 & 0.354 \\
\hline & $\begin{array}{l}\text { Specific Leaf Area } \\
\qquad\left(\mathrm{cm}^{2}\right)\end{array}$ & $\mathrm{S} * \mathrm{~L}+\mathrm{S}+\mathrm{L}$ & 715.6 & 1 & 0.331 & 0.411 \\
\hline \multirow[t]{10}{*}{ Final } & $\begin{array}{c}\text { Glucose } \\
\text { (mg g }{ }^{-1} \text { dry wt) }\end{array}$ & $\mathrm{F} * \mathrm{~S}+\mathrm{F}+\mathrm{S}$ & 3432 & 0.421 & 0.210 & 0.518 \\
\hline & $\begin{array}{c}\text { Sucrose } \\
\left(\mathrm{mg} \mathrm{g}^{-1} \text { dry wt) }\right.\end{array}$ & $\mathrm{F} * \mathrm{~S}+\mathrm{F}+\mathrm{S}$ & 3965 & 0.411 & 0.162 & 0.338 \\
\hline & Starch $(\%)$ & S & 2724 & 0.555 & 0.090 & 0.291 \\
\hline & $\begin{array}{l}\text { Aboveground } \\
\text { Biomass (g) }\end{array}$ & S & 1587 & 0.505 & 0.009 & 0.072 \\
\hline & $\begin{array}{l}\text { Specific Leaf Area } \\
\qquad\left(\mathrm{cm}^{2}\right)\end{array}$ & $\mathrm{F}^{*} \mathrm{~S} * \mathrm{~L}+\mathrm{F}^{*} \mathrm{~S}+\mathrm{F}^{*} \mathrm{~L}+\mathrm{S} * \mathrm{~L}+\mathrm{F}+\mathrm{S}+\mathrm{L}$ & 3555 & 1 & 0.050 & 0.318 \\
\hline & $\begin{array}{c}\text { Leaf Water Content } \\
(\%)\end{array}$ & $\mathrm{F} * \mathrm{~S} * \mathrm{~L}+\mathrm{F} * \mathrm{~S}+\mathrm{F} * \mathrm{~L}+\mathrm{S} * \mathrm{~L}+\mathrm{F}+\mathrm{S}+\mathrm{L}$ & 2258 & 1 & 0.129 & 0.487 \\
\hline & Leaf Toughness & $\mathrm{F}$ & 647.9 & 0.503 & 0.005 & 0.039 \\
\hline & Leaf Damage (\%) & $\mathrm{F}$ & 2350 & 1 & 0.007 & 0.351 \\
\hline & $\begin{array}{l}\text { Mean FAW } \\
\text { Biomass }\end{array}$ & Intercept & -348 & 0.64 & 0.000 & 0.200 \\
\hline & $\begin{array}{c}\text { Mean \# of } S . \\
\text { frugiperda larvae }\end{array}$ & Intercept & 369.3 & 1 & 0.000 & 0.023 \\
\hline
\end{tabular}


Table 5 | Least square means of each plant trait measured for each lineage under each treatment. Least square means were determined using the GLMM model that combined both fall armyworm (FAW) presence and salinity to determine the means for each treatment as well as determine the impact of FAW and salinity separately as well as together. Different letters indicate a significance where $p<0.05$.

\begin{tabular}{|c|c|c|c|c|c|c|c|c|c|c|c|c|}
\hline \multicolumn{3}{|c|}{ Treatment } & \multicolumn{10}{|c|}{ Plant Trait } \\
\hline Lineage & FAW & Salinity & $\begin{array}{l}\text { Glucose } \\
\text { (mg g-1 } \\
\text { dry wt.) }\end{array}$ & $\begin{array}{l}\text { Sucrose } \\
\text { (mg g-1 } \\
\text { dry wt.) }\end{array}$ & $\begin{array}{c}\text { Starch } \\
(\%)\end{array}$ & $\begin{array}{c}\text { Above } \\
\text { ground } \\
\text { Biomass } \\
\text { (g) }\end{array}$ & $\begin{array}{c}\text { Specific } \\
\text { Leaf } \\
\text { Area } \\
\left(\mathrm{cm}^{2}\right)\end{array}$ & $\begin{array}{c}\text { Leaf } \\
\text { Water } \\
\text { Content } \\
(\%)\end{array}$ & $\begin{array}{c}\text { Leaf } \\
\text { Toughnes } \\
\text { s }\end{array}$ & $\begin{array}{c}\text { Leaf } \\
\text { Damage } \\
(\%)\end{array}$ & $\begin{array}{c}\text { Mean } \\
\text { Larvae } \\
\text { Biomass } \\
(\mathbf{m g})\end{array}$ & $\begin{array}{c}\text { Mean \# } \\
\text { of } \\
\text { Larvae }\end{array}$ \\
\hline \multirow[t]{6}{*}{ Native } & No & 0 & $\begin{array}{l}3.12 \pm \\
0.38 \mathrm{a}\end{array}$ & $\begin{array}{l}4.79 \pm \\
0.22 \mathrm{a}\end{array}$ & $\begin{array}{l}2.07 \pm \\
0.37 \\
\text { acd }\end{array}$ & $\begin{array}{l}1.49 \pm \\
0.01 \mathrm{~h}\end{array}$ & $\begin{array}{l}248.06 \pm \\
13.18 \mathrm{a}\end{array}$ & $\begin{array}{l}83.21 \pm \\
2.23 \mathrm{ab}\end{array}$ & $\begin{array}{l}0.80 \pm \\
0.08 \mathrm{a}\end{array}$ & $\begin{array}{l}0.06 \pm \\
0.01 \mathrm{c}\end{array}$ & & \\
\hline & & 5 & $\begin{array}{l}3.98 \pm \\
0.35 \mathrm{ab}\end{array}$ & $\begin{array}{l}4.68 \pm \\
0.23 \mathrm{a}\end{array}$ & $\begin{array}{l}2.87 \pm \\
0.37 \\
\text { abcdef }\end{array}$ & $\begin{array}{l}1.22 \pm \\
0.01 \mathrm{e}\end{array}$ & $\begin{array}{l}245.2 \pm \\
13.82 \mathrm{a}\end{array}$ & $\begin{array}{l}80.17 \pm \\
2.27 \mathrm{a}\end{array}$ & $\begin{array}{l}0.83 \pm \\
0.08 \mathrm{a}\end{array}$ & $\begin{array}{l}0.49 \pm \\
0.01 \mathrm{~d}\end{array}$ & & \\
\hline & & 15 & $\begin{array}{l}3.98 \pm \\
0.32 \mathrm{ab}\end{array}$ & $\begin{array}{l}4.93 \pm \\
0.2 \mathrm{ab}\end{array}$ & $\begin{array}{l}3.57 \pm \\
0.34 \text { ef }\end{array}$ & $\begin{array}{l}0.96 \pm \\
0.01 \mathrm{~b}\end{array}$ & $\begin{array}{l}242.42 \pm \\
12.27 \mathrm{a}\end{array}$ & $\begin{array}{l}85.54 \pm \\
2.07 \mathrm{ab}\end{array}$ & $\begin{array}{l}0.73 \pm \\
0.08 \mathrm{a}\end{array}$ & $\begin{array}{l}0.97 \pm \\
0.01 \mathrm{f}\end{array}$ & & \\
\hline & Yes & 0 & $\begin{array}{l}4.54 \pm \\
0.37 \mathrm{ab}\end{array}$ & $\begin{array}{l}4.72 \pm \\
0.23 \mathrm{a}\end{array}$ & $\begin{array}{l}2.63 \pm \\
0.36 \\
\text { abcdef }\end{array}$ & $\begin{array}{l}1.38 \pm \\
0.01 \mathrm{f}\end{array}$ & $\begin{array}{l}222.84 \pm \\
13.18 \mathrm{a}\end{array}$ & $\begin{array}{l}85.55 \pm \\
2.23 \mathrm{ab}\end{array}$ & $\begin{array}{l}0.68 \pm \\
0.08 \mathrm{a}\end{array}$ & $\begin{array}{l}1.83 \pm \\
0.01 \mathrm{k}\end{array}$ & $\begin{array}{l}0.05 \pm \\
0.02 \mathrm{a}\end{array}$ & $\begin{array}{l}1.117 \pm \\
0.090 \mathrm{a}\end{array}$ \\
\hline & & 5 & $\begin{array}{l}3.23 \pm \\
0.37 \mathrm{ab}\end{array}$ & $\begin{array}{l}4.94 \pm \\
0.22 \mathrm{ab}\end{array}$ & $\begin{array}{l}2.68 \pm \\
0.35 \\
\text { abcdef }\end{array}$ & $\begin{array}{l}1.43 \pm \\
0.01 \mathrm{~g}\end{array}$ & $\begin{array}{l}230.54 \pm \\
13.07 \mathrm{a}\end{array}$ & $\begin{array}{l}85.13 \pm \\
2.21 \mathrm{ab}\end{array}$ & $\begin{array}{l}0.74 \pm \\
0.08 \mathrm{a}\end{array}$ & $\begin{array}{l}1.64 \pm \\
0.01 \mathrm{i}\end{array}$ & $\begin{array}{l}0.02 \pm \\
0.02 \mathrm{a}\end{array}$ & $\begin{array}{l}1.027 \pm \\
0.102 \mathrm{a}\end{array}$ \\
\hline & & 15 & $\begin{array}{l}3.61 \pm \\
0.37 \mathrm{ab}\end{array}$ & $\begin{array}{l}5.72 \pm \\
0.22 \mathrm{~b}\end{array}$ & $\begin{array}{l}3.33 \pm \\
0.35 \text { bef }\end{array}$ & $\begin{array}{l}0.79 \pm \\
0.01 \mathrm{a}\end{array}$ & $\begin{array}{l}228.1 \pm \\
13.02 \mathrm{a}\end{array}$ & $\begin{array}{l}91.22 \pm \\
2.21 \mathrm{~b}\end{array}$ & $\begin{array}{l}0.68 \pm \\
0.08 \mathrm{a}\end{array}$ & $\begin{array}{l}1.72 \pm \\
0.01 \mathrm{j}\end{array}$ & $\begin{array}{l}0.03 \pm \\
0.02 \mathrm{a}\end{array}$ & $\begin{array}{l}1.182 \pm \\
0.086 \mathrm{a}\end{array}$ \\
\hline \multirow[t]{6}{*}{ Introduced } & No & 0 & $\begin{array}{l}3.17 \pm \\
0.38 \mathrm{a}\end{array}$ & $\begin{array}{l}4.9 \pm \\
0.23 \mathrm{ab}\end{array}$ & $\begin{array}{l}1.73 \pm \\
0.35 \mathrm{ab}\end{array}$ & $\begin{array}{l}1.43 \pm \\
0.01 \mathrm{~g}\end{array}$ & $\begin{array}{l}250.03 \pm \\
12.92 \mathrm{a}\end{array}$ & $\begin{array}{l}85.9 \pm \\
2.2 \mathrm{ab}\end{array}$ & $\begin{array}{l}0.69 \pm \\
0.08 \mathrm{a}\end{array}$ & $\begin{array}{l}0.06 \pm \\
0.0 \mathrm{c}\end{array}$ & & \\
\hline & & 5 & $\begin{array}{l}4.19 \pm \\
0.37 \mathrm{ab}\end{array}$ & $\begin{array}{l}4.87 \pm \\
0.24 \mathrm{ab}\end{array}$ & $\begin{array}{l}2.86 \pm \\
0.39 \\
\text { abcdef }\end{array}$ & $\begin{array}{l}1.54 \pm \\
0.01 \mathrm{i}\end{array}$ & $\begin{array}{l}254.67 \pm \\
14.51 \mathrm{a}\end{array}$ & $\begin{array}{l}84.2 \pm \\
2.4 \mathrm{ab}\end{array}$ & $\begin{array}{l}0.72 \pm \\
0.09 \mathrm{a}\end{array}$ & $\begin{array}{l}-0.37 \pm \\
0.01 \mathrm{a}\end{array}$ & & \\
\hline & & 15 & $\begin{array}{l}4.48 \pm \\
0.3 \mathrm{ab}\end{array}$ & $\begin{array}{l}5.04 \pm \\
0.19 \mathrm{ab}\end{array}$ & $\begin{array}{l}3.36 \pm \\
0.33 \mathrm{df}\end{array}$ & $\begin{array}{l}1.18 \pm \\
0.01 \mathrm{~d}\end{array}$ & $\begin{array}{l}236.84 \pm \\
11.79 \mathrm{a}\end{array}$ & $\begin{array}{l}88.92 \pm \\
1.99 \mathrm{ab}\end{array}$ & $\begin{array}{l}0.76 \pm \\
0.07 \mathrm{a}\end{array}$ & $\begin{array}{l}0.01 \pm \\
0.01 \mathrm{~b}\end{array}$ & & \\
\hline & Yes & 0 & $\begin{array}{l}4.84 \pm \\
0.37 \mathrm{~b}\end{array}$ & $\begin{array}{l}4.8 \pm \\
0.22 \mathrm{ab}\end{array}$ & $\begin{array}{l}2.11 \pm \\
0.36 \\
\text { abce }\end{array}$ & $\begin{array}{l}1.67 \pm \\
0.01 \mathrm{j}\end{array}$ & $\begin{array}{l}228.58 \pm \\
12.92 \mathrm{a}\end{array}$ & $\begin{array}{l}86.91 \pm \\
2.2 \mathrm{ab}\end{array}$ & $\begin{array}{l}0.63 \pm \\
0.08 \mathrm{a}\end{array}$ & $\begin{array}{l}1.27 \pm \\
0.01 \mathrm{~g}\end{array}$ & $\begin{array}{l}0.07 \pm \\
0.02 \mathrm{a}\end{array}$ & $\begin{array}{l}1.120 \pm \\
0.092 \mathrm{a}\end{array}$ \\
\hline & & 5 & $\begin{array}{l}3.24 \pm \\
0.37 \mathrm{ab}\end{array}$ & $\begin{array}{l}4.96 \pm \\
0.22 \mathrm{ab}\end{array}$ & $\begin{array}{l}2.74 \pm \\
0.35 \\
\text { abcdef }\end{array}$ & $\begin{array}{l}1.4 \pm \\
0.01 \mathrm{fg}\end{array}$ & $\begin{array}{l}219.05 \pm \\
13.0 \mathrm{a}\end{array}$ & $\begin{array}{l}85.47 \pm \\
2.21 \mathrm{ab}\end{array}$ & $\begin{array}{l}0.65 \pm \\
0.08 \mathrm{a}\end{array}$ & $\begin{array}{l}0.88 \pm \\
0.01 \mathrm{e}\end{array}$ & $\begin{array}{l}0.04 \pm \\
0.02 \mathrm{a}\end{array}$ & $\begin{array}{l}0.953 \pm \\
0.097 \mathrm{a}\end{array}$ \\
\hline & & 15 & $\begin{array}{l}3.77 \pm \\
0.37 \mathrm{ab}\end{array}$ & $\begin{array}{l}5.64 \pm \\
0.22 \mathrm{ab}\end{array}$ & $\begin{array}{l}3.19 \pm \\
0.34 \\
\text { cdef }\end{array}$ & $\begin{array}{l}1.11 \pm \\
0.01 \mathrm{c}\end{array}$ & $\begin{array}{l}223.3 \pm \\
12.59 \mathrm{a}\end{array}$ & $\begin{array}{l}90.43 \pm \\
2.15 \mathrm{ab}\end{array}$ & $\begin{array}{l}0.66 \pm \\
0.08 \mathrm{a}\end{array}$ & $\begin{array}{l}1.37 \pm \\
0.01 \mathrm{~h}\end{array}$ & $\begin{array}{l}0.02 \pm \\
0.02 \mathrm{a}\end{array}$ & $\begin{array}{l}0.867 \pm \\
0.101 \mathrm{a}\end{array}$ \\
\hline
\end{tabular}


Table S1a | Correlations among P. australis traits for the North American native lineage. Each correlation has a p-value (top) and $\mathrm{R}^{2}$ (bottom). Highlighted blocks are correlations that have a p-value $<0.05$.

\begin{tabular}{|c|c|c|c|c|c|c|c|c|c|c|}
\hline Native & $\begin{array}{r}\text { Glucose } \\
\text { (above) }\end{array}$ & $\begin{array}{l}\text { Sucrose } \\
\text { (above) }\end{array}$ & $\begin{array}{c}\text { Starch } \\
\text { (\%) } \\
\text { (below) }\end{array}$ & $\begin{array}{c}\text { Above } \\
\text { ground } \\
\text { Biomass (g) }\end{array}$ & $\begin{array}{c}\text { Specific } \\
\text { Leaf Area } \\
\left(\mathrm{cm}^{2}\right)\end{array}$ & $\begin{array}{c}\text { Leaf Water } \\
\text { Content } \\
(\%)\end{array}$ & $\begin{array}{c}\text { Leaf } \\
\text { Toughness }\end{array}$ & $\begin{array}{c}\text { Leaf } \\
\text { Damage } \\
(\%)\end{array}$ & $\begin{array}{c}\text { Mean \# } \\
\text { of } \\
\text { Larvae }\end{array}$ & $\begin{array}{c}\text { Mean } \\
\text { Larvae } \\
\text { Biomass }\end{array}$ \\
\hline $\begin{array}{r}\text { Glucose } \\
\text { (above) }\end{array}$ & 1 & & & & & & & & & \\
\hline \multirow{2}{*}{$\begin{array}{l}\text { Sucrose } \\
\text { (above) }\end{array}$} & 0.22 & 1 & & & & & & & & \\
\hline & 0.005 & & & & & & & & & \\
\hline \multirow{2}{*}{$\begin{array}{c}\text { Starch (\%) } \\
\text { (below) }\end{array}$} & 0.11 & 0.045 & 1 & & & & & & & \\
\hline & 0.17 & 0.569 & & & & & & & & \\
\hline \multirow{2}{*}{$\begin{array}{c}\text { Aboveground } \\
\text { Biomass (g) }\end{array}$} & -0.09 & -0.20 & 0.10 & 1 & & & & & & \\
\hline & 0.253 & 0.011 & 0.181 & & & & & & & \\
\hline \multirow{2}{*}{$\begin{array}{c}\text { Specific Leaf } \\
\text { Area }\left(\mathrm{cm}^{2}\right)\end{array}$} & -0.088 & 0.037 & -0.017 & 0.08 & 1 & & & & & \\
\hline & 0.268 & 0.643 & 0.827 & 0.299 & & & & & & \\
\hline \multirow{2}{*}{$\begin{array}{l}\text { Leaf Water } \\
\text { Content (\%) }\end{array}$} & 0.40 & 0.63 & 0.049 & -0.31 & -0.063 & 1 & & & & \\
\hline & $<0.001$ & $<0.001$ & 0.531 & $<0.001$ & 0.412 & & & & & \\
\hline \multirow{2}{*}{$\begin{array}{c}\text { Leaf } \\
\text { Toughness }\end{array}$} & -0.18 & -0.28 & -0.10 & 0.044 & 0.077 & -0.34 & 1 & & & \\
\hline & 0.023 & $<0.001$ & 0.175 & 0.568 & 0.32 & $<0.001$ & & & & \\
\hline \multirow{2}{*}{$\begin{array}{l}\text { Leaf Damage } \\
(\%)\end{array}$} & 0.084 & 0.067 & -0.10 & -0.20 & -0.17 & 0.17 & -0.14 & 1 & & \\
\hline & 0.298 & 0.407 & 0.205 & 0.008 & 0.028 & 0.026 & 0.081 & & & \\
\hline \multirow{2}{*}{$\begin{array}{l}\text { Mean \# of } \\
\text { Larvae }\end{array}$} & -0.24 & -0.046 & 0.092 & -0.049 & 0.14 & -0.13 & 0.18 & -0.054 & 1 & \\
\hline & 0.08 & 0.738 & 0.491 & 0.712 & 0.279 & 0.342 & 0.164 & 0.693 & & \\
\hline Mean & 0.065 & -0.045 & -0.044 & 0.29 & -0.065 & 0.18 & -0.20 & 0.16 & -0.028 & 1 \\
\hline $\begin{array}{l}\text { Larvae } \\
\text { Biomass }\end{array}$ & 0.637 & 0.745 & 0.744 & 0.028 & 0.627 & 0.182 & 0.121 & 0.251 & 0.844 & \\
\hline
\end{tabular}


Table S1b | Correlations among P. australis traits for the introduced lineage. Each correlation has a p-value (top) and $\mathrm{R}^{2}$ (bottom). Highlighted blocks are correlations that have a p-value $<0.05$

\begin{tabular}{|c|c|c|c|c|c|c|c|c|c|c|}
\hline Introduced & $\begin{array}{l}\text { Glucose } \\
\text { (above) }\end{array}$ & $\begin{array}{l}\text { Sucrose } \\
\text { (above) }\end{array}$ & $\begin{array}{c}\text { Starch } \\
(\%) \\
\text { (below) }\end{array}$ & $\begin{array}{c}\text { Above } \\
\text { ground } \\
\text { Biomass (g) }\end{array}$ & $\begin{array}{c}\text { Specific } \\
\text { Leaf Area } \\
\left(\mathrm{cm}^{2}\right)\end{array}$ & $\begin{array}{c}\text { Leaf } \\
\text { Water } \\
\text { Content } \\
(\%)\end{array}$ & $\begin{array}{c}\text { Leaf } \\
\text { Toughness }\end{array}$ & $\begin{array}{c}\text { Leaf } \\
\text { Damage } \\
(\%)\end{array}$ & $\begin{array}{c}\text { Mean \# } \\
\text { of } \\
\text { Larvae }\end{array}$ & $\begin{array}{c}\text { Mean } \\
\text { Larvae } \\
\text { Biomass }\end{array}$ \\
\hline $\begin{array}{l}\text { Glucose } \\
\text { (above) }\end{array}$ & 1 & & & & & & & & & \\
\hline \multirow{2}{*}{$\begin{array}{l}\text { Sucrose } \\
\text { (above) }\end{array}$} & 0.055 & 1 & & & & & & & & \\
\hline & 0.468 & & & & & & & & & \\
\hline \multirow{2}{*}{$\begin{array}{c}\text { Starch (\%) } \\
\text { (below) }\end{array}$} & -0.16 & 0.051 & 1 & & & & & & & \\
\hline & 0.039 & 0.507 & & & & & & & & \\
\hline \multirow{2}{*}{$\begin{array}{c}\text { Abovegrou } \\
\text { nd Biomass } \\
\text { (g) }\end{array}$} & -0.067 & -0.069 & 0.088 & 1 & & & & & & \\
\hline & 0.377 & 0.359 & 0.241 & & & & & & & \\
\hline \multirow{2}{*}{$\begin{array}{c}\text { Specific } \\
\text { Leaf } \\
\text { Area }\left(\mathrm{cm}^{2}\right)\end{array}$} & 0.19 & 0.033 & -0.30 & -0.063 & 1 & & & & & \\
\hline & 0.012 & 0.67 & $<0.001$ & 0.403 & & & & & & \\
\hline \multirow{2}{*}{$\begin{array}{c}\text { Leaf Water } \\
\text { Content } \\
(\%)\end{array}$} & 0.39 & 0.58 & -0.038 & -0.23 & 0.077 & 1 & & & & \\
\hline & $<0.001$ & $<0.001$ & 0.623 & 0.002 & 0.306 & & & & & \\
\hline \multirow{2}{*}{$\begin{array}{c}\text { Leaf } \\
\text { Toughness }\end{array}$} & -0.20 & -0.25 & 0.25 & 0.06 & -0.097 & -0.43 & 1 & & & \\
\hline & 0.008 & 0.001 & 0.001 & 0.425 & 0.197 & $<0.001$ & & & & \\
\hline \multirow{2}{*}{$\begin{array}{c}\text { Leaf } \\
\text { Damage } \\
(\%)\end{array}$} & 0.058 & 0.10 & -0.23 & -0.045 & -0.02 & 0.14 & -0.18 & 1 & & \\
\hline & 0.449 & 0.192 & 0.002 & 0.557 & 0.79 & 0.072 & 0.016 & & & \\
\hline \multirow{2}{*}{$\begin{array}{l}\text { Mean \# of } \\
\text { Larvae }\end{array}$} & -0.09 & -0.091 & -0.15 & -0.031 & -0.026 & -0.088 & -0.21 & -0.10 & 1 & \\
\hline & 0.492 & 0.488 & 0.26 & 0.809 & 0.843 & 0.495 & 0.098 & 0.439 & & \\
\hline Mean & 0.21 & -0.26 & -0.11 & 0.34 & -0.13 & 0.031 & -0.0086 & 0.091 & 0.12 & 1 \\
\hline $\begin{array}{c}\text { Larvae } \\
\text { Biomass }\end{array}$ & 0.105 & 0.046 & 0.397 & 0.007 & 0.318 & 0.812 & 0.677 & 0.499 & 0.359 & \\
\hline
\end{tabular}


Table S2 | Summary of model selection results for all variables. Best model is the model with the smallest AIC value. In the case of ties, the better model is the one with the fewest parameters. Additional supported models $(\triangle \mathrm{AIC} \leq 2.0)$ are also included. $\mathrm{F}=S$.

frugiperda presence (yes, no), $\mathrm{T}=$ stage (initial, final), $\mathrm{S}=$ salinity treatment $(0,5,15 \mathrm{ppt})$. Goodness of fit statistics are represented by $\mathrm{R}^{2}$-fixed, or marginal $\mathrm{R}^{2}$, and $\mathrm{R}^{2}$-model, or conditional $\mathrm{R}^{2}$.

\begin{tabular}{|c|c|c|c|c|c|c|c|}
\hline & $\begin{array}{c}\text { Response } \\
\text { Variable }\end{array}$ & AIC-Best Model & AIC & $\Delta \mathrm{AIC}$ & $\begin{array}{l}\text { Akaike } \\
\text { Wt. }\end{array}$ & $R^{2}$-fixed & $\mathbf{R}^{2}$-model \\
\hline \multirow[t]{14}{*}{ Initial } & Glucose & $\mathrm{S} * \mathrm{~L}+\mathrm{S}+\mathrm{L}$ & 638.7 & 0 & 1 & 0.000 & 0.413 \\
\hline & Sucrose & S & 637.5 & 0 & 0.461 & 0.044 & 0.171 \\
\hline & & Intercept & 638.1 & 0.6 & 0.356 & & \\
\hline & & $\mathrm{S}+\mathrm{L}$ & 639.4 & 1.9 & 0.183 & & \\
\hline & Starch $(\%)$ & $\mathrm{S} * \mathrm{~L}+\mathrm{S}+\mathrm{L}$ & 377.7 & 0 & 0.492 & 0.368 & 0.368 \\
\hline & & S & 379 & 1.3 & 0.253 & & \\
\hline & & $\mathrm{S}+\mathrm{L}$ & 379 & 1.3 & 0.254 & & \\
\hline & Aboveground & Intercept & 175.2 & 0 & 0.507 & 0.000 & 0.354 \\
\hline & & S & 176.5 & 1.3 & 0.266 & & \\
\hline & & $\mathrm{L}$ & 176.8 & 1.6 & 0.227 & & \\
\hline & $\begin{array}{l}\text { Specific Leaf } \\
\text { Area }\left(\mathrm{cm}^{2}\right)\end{array}$ & $\mathrm{S} * \mathrm{~L}+\mathrm{S}+\mathrm{L}$ & 715.6 & 0 & 1 & 0.331 & 0.411 \\
\hline & $\begin{array}{l}\text { Leaf Water } \\
\text { Content }(\%)\end{array}$ & $\mathrm{S} * \mathrm{~L}+\mathrm{S}+\mathrm{L}$ & 453.8 & 0 & 1 & 0.174 & 0.236 \\
\hline & Leaf & Intercept & 98.7 & 0 & 0.692 & 0.000 & 0.206 \\
\hline & & $\mathrm{L}$ & 100.3 & 1.6 & 0.308 & & \\
\hline \multirow[t]{12}{*}{ Final } & Glucose & $\mathrm{F} * \mathrm{~S}+\mathrm{F}+\mathrm{S}$ & 3432 & 0 & 0.421 & 0.210 & 0.518 \\
\hline & & $\mathrm{F} * \mathrm{~S}+\mathrm{F}+\mathrm{S}+\mathrm{L}$ & 3432 & 0.2 & 0.391 & & \\
\hline & & $\mathrm{F} * \mathrm{~S}+\mathrm{F} * \mathrm{~L}+\mathrm{F}+\mathrm{S}+\mathrm{L}$ & 3433 & 1.6 & 0.188 & & \\
\hline & Sucrose & $\mathrm{F} * \mathrm{~S}+\mathrm{F}+\mathrm{S}$ & 3965 & 0 & 0.411 & 0.162 & 0.338 \\
\hline & & $\mathrm{F}+\mathrm{S}$ & 3966 & 0.9 & 0.259 & & \\
\hline & & S & 3967 & 1.8 & 0.166 & & \\
\hline & & $\mathrm{F} * \mathrm{~S}+\mathrm{F}+\mathrm{S}+\mathrm{L}$ & 3967 & 1.9 & 0.164 & & \\
\hline & Starch $(\%)$ & S & 2724 & 0 & 0.555 & 0.090 & 0.291 \\
\hline & & $\mathrm{S}+\mathrm{L}$ & 2726 & 1.7 & 0.237 & & \\
\hline & & $\mathrm{F}+\mathrm{S}$ & 2726 & 2 & 0.208 & & \\
\hline & Aboveground & S & 1587 & 0 & 0.505 & 0.009 & 0.072 \\
\hline & & $\mathrm{S}+\mathrm{L}$ & 1588 & 1.1 & 0.29 & & \\
\hline
\end{tabular}




\begin{tabular}{|c|c|c|c|c|c|c|}
\hline & $\mathrm{F}+\mathrm{S}$ & 1588 & 1.8 & 0.205 & & \\
\hline $\begin{array}{l}\text { Specific Leaf } \\
\text { Area }\left(\mathrm{cm}^{2}\right)\end{array}$ & $\mathrm{F} * \mathrm{~S} * \mathrm{~L}+\mathrm{F} * \mathrm{~S}+\mathrm{F} * \mathrm{~L}+\mathrm{S} * \mathrm{~L}+\mathrm{F}+\mathrm{S}+\mathrm{L}$ & 3555 & 0 & 1 & 0.050 & 0.318 \\
\hline $\begin{array}{l}\text { Leaf Water } \\
\text { Content }(\%)\end{array}$ & $\mathrm{F} * \mathrm{~S} * \mathrm{~L}+\mathrm{F} * \mathrm{~S}+\mathrm{F} * \mathrm{~L}+\mathrm{S} * \mathrm{~L}+\mathrm{F}+\mathrm{S}+\mathrm{L}$ & 2258 & 0 & 1 & 0.129 & 0.487 \\
\hline \multirow{3}{*}{$\begin{array}{c}\text { Leaf } \\
\text { Toughness }\end{array}$} & $\mathrm{F}$ & 647.9 & 0 & 0.503 & 0.005 & 0.039 \\
\hline & Intercept & 649.2 & 1.3 & 0.265 & & \\
\hline & $\mathrm{F}+\mathrm{L}$ & 649.5 & 1.6 & 0.232 & & \\
\hline $\begin{array}{c}\text { Leaf Damage } \\
(\%)\end{array}$ & $\mathrm{F}$ & 2350 & 0 & 1 & 0.007 & 0.351 \\
\hline Mean & Intercept & -348 & 0 & 0.64 & 0.000 & 0.200 \\
\hline \multicolumn{7}{|l|}{ S. frugiperda } \\
\hline Biomass & $\mathrm{S}$ & -347 & 1.2 & 0.36 & & \\
\hline $\begin{array}{l}\text { Mean \# of } \\
\text { S. frugiperda } \\
\text { larvae }\end{array}$ & Intercept & 369.3 & 0 & 1 & 0.000 & 0.023 \\
\hline
\end{tabular}




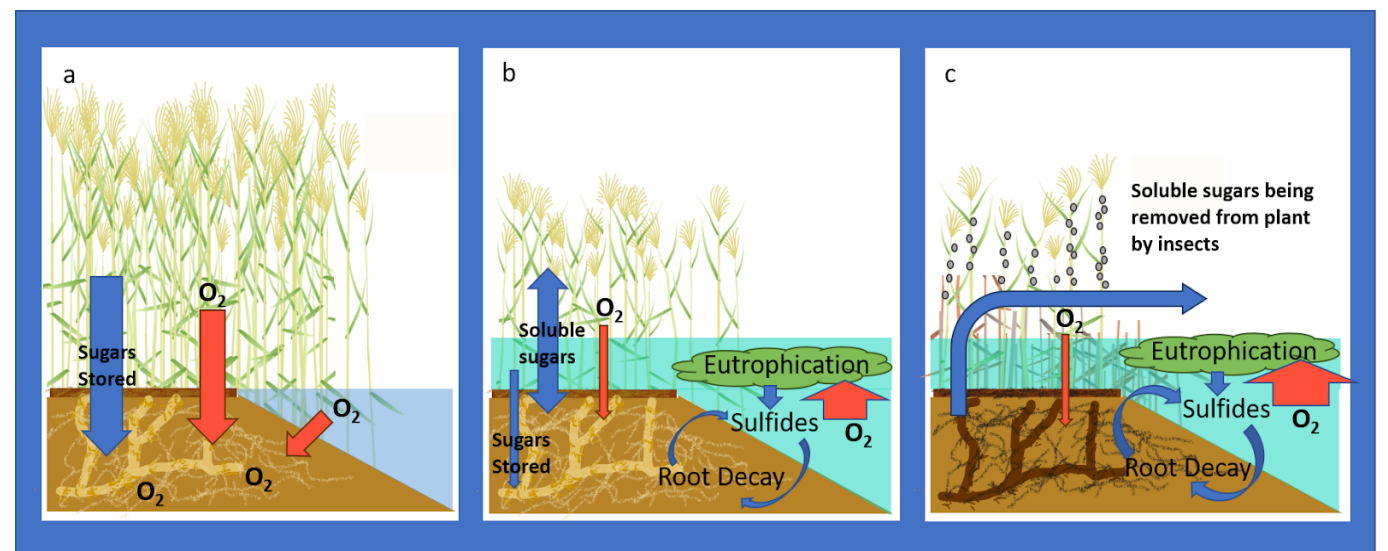

Figure 1 | Panels portray a variety of environmental conditions that could impact reed death and the biogeochemistry of the coastline: (a) P. australis growing in a non-flooded freshwater environment where oxygen can effectively reach the roots and sugars are being stored in the rhizomes after peak growth has been acheived; (b) $P$. australis growing in flooded, saline environment using soluble sugars to ameliorate environmental stressors; (c) Insects consuming available soluble sugars, removing $P$. australis's primary defense against environmental stress, exacerbating reed death. Figure by Jennifer Soukup 


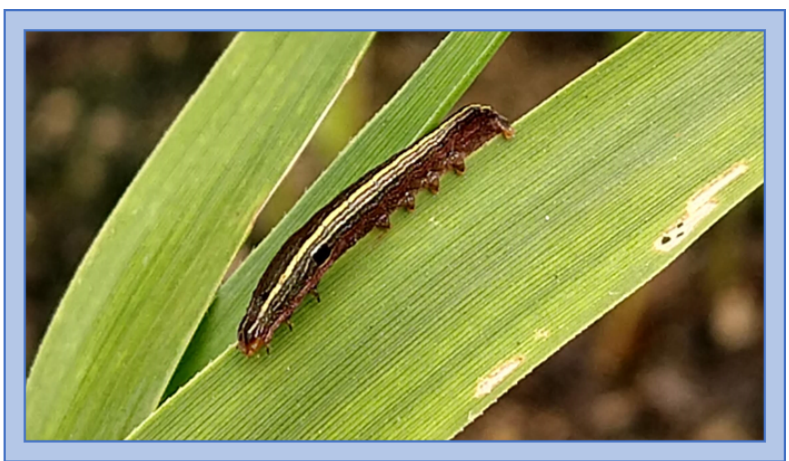

Figure 2 | Presence of Spodoptera frugiperda, the fall armyworm, on P. australis. Photo provided by Jennifer Soukup 


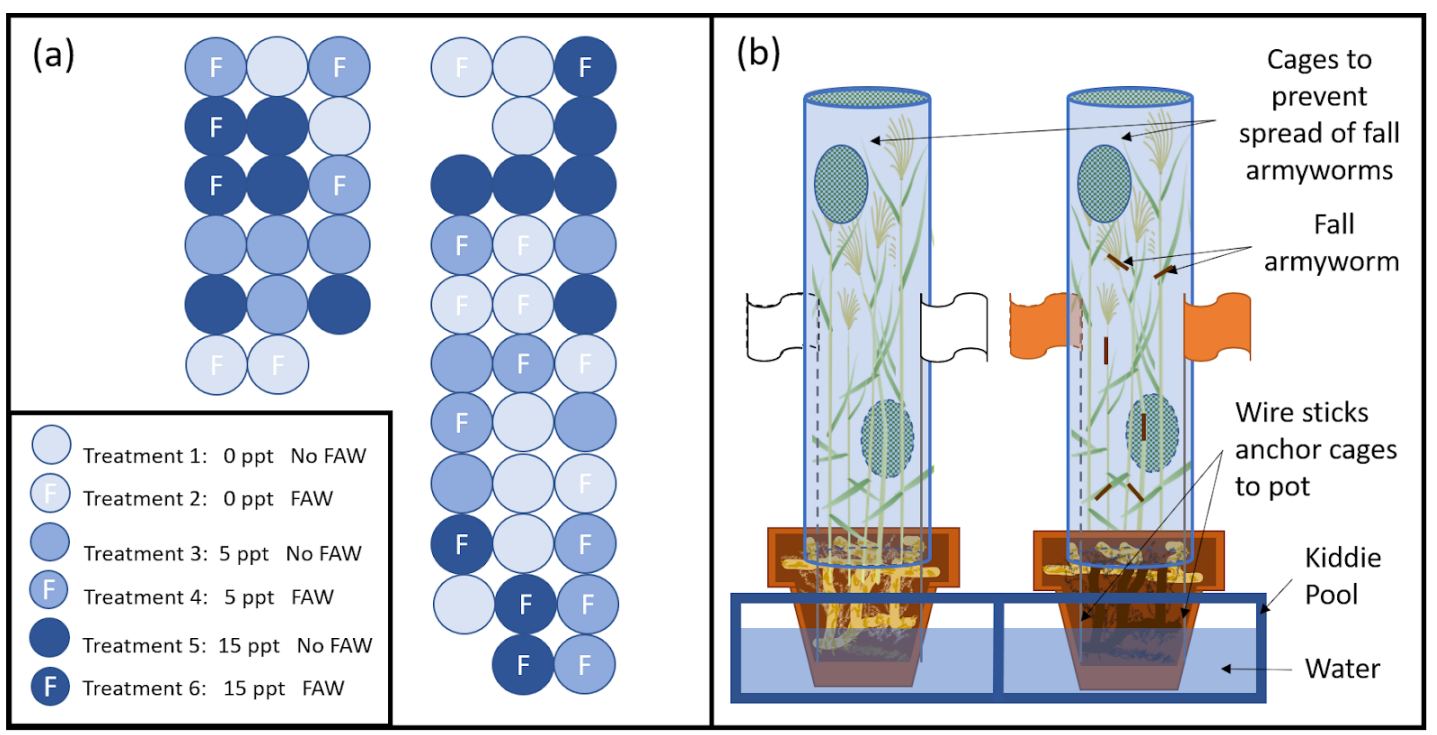

Figure 3 | Experimental design for RI greenhouse study. (a) Birds-eye view of the study showing 6 treatments and key; each treatment will have 8 replicates (i.e. kiddie pools) and each replicate having 10 pots ( 5 invasive and 5 native). (b) Closer view of cages and fall armyworms that will be applied; cages will be composed of acetate sheets and will contain three holes covered with mesh netting (represented by green checkered pattern); white/orange flags indicate control/experimental pots, respectively, and the wiring of the flags will be stuck into the pot to anchor the cages to the pot. Figure by Jennifer Soukup 
(a)

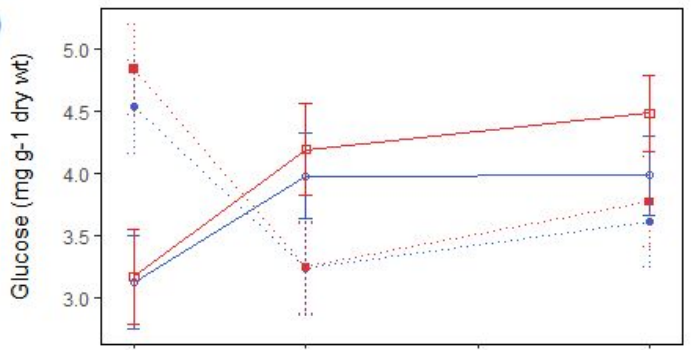

(c)

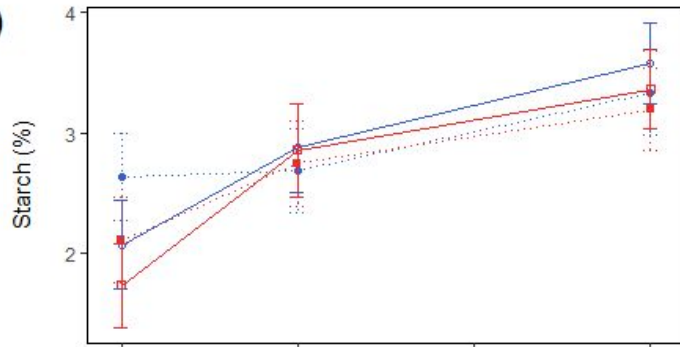

(e)

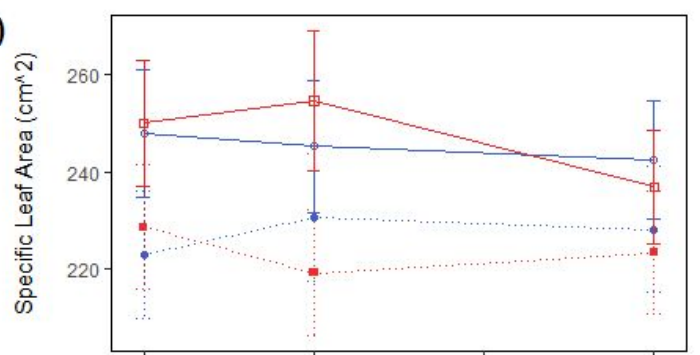

(g)

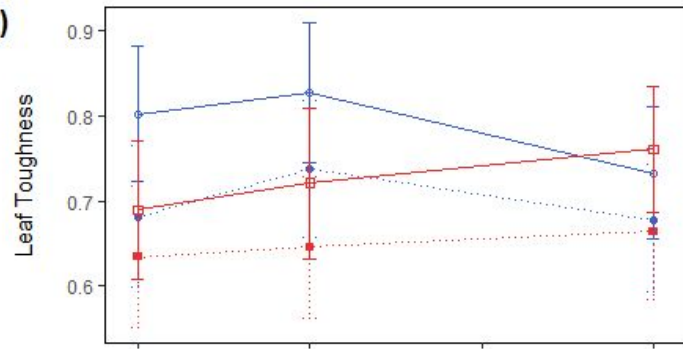

(i)

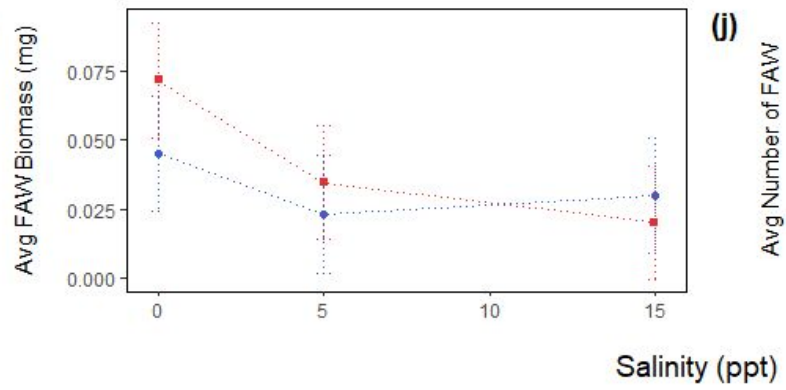

(b)

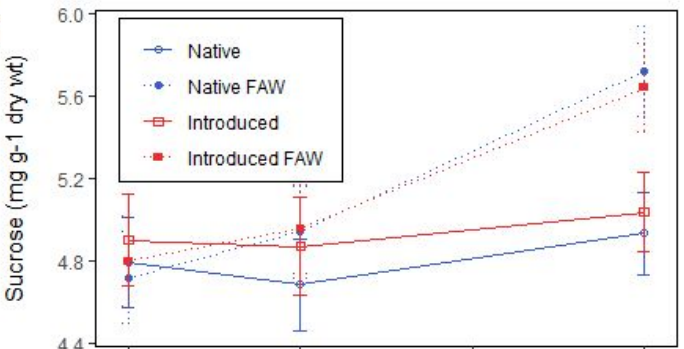

(d)

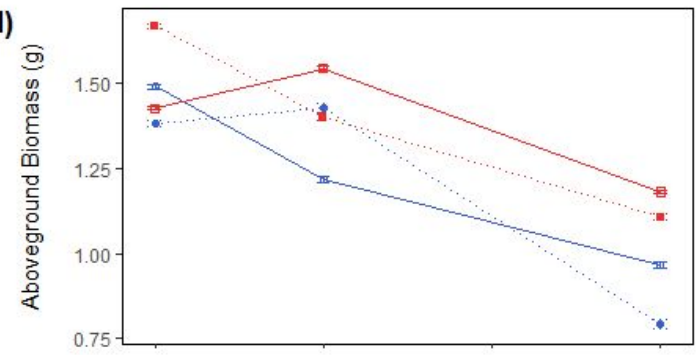

(f)

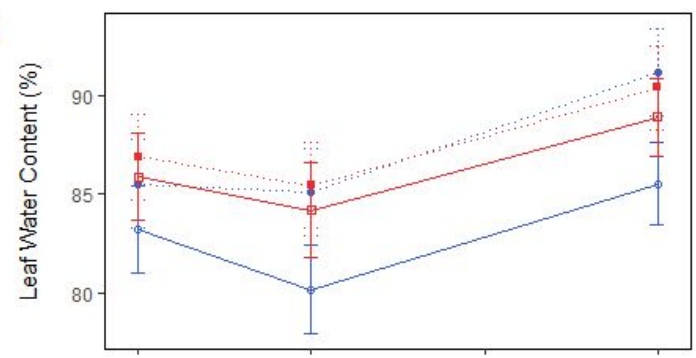

(h)
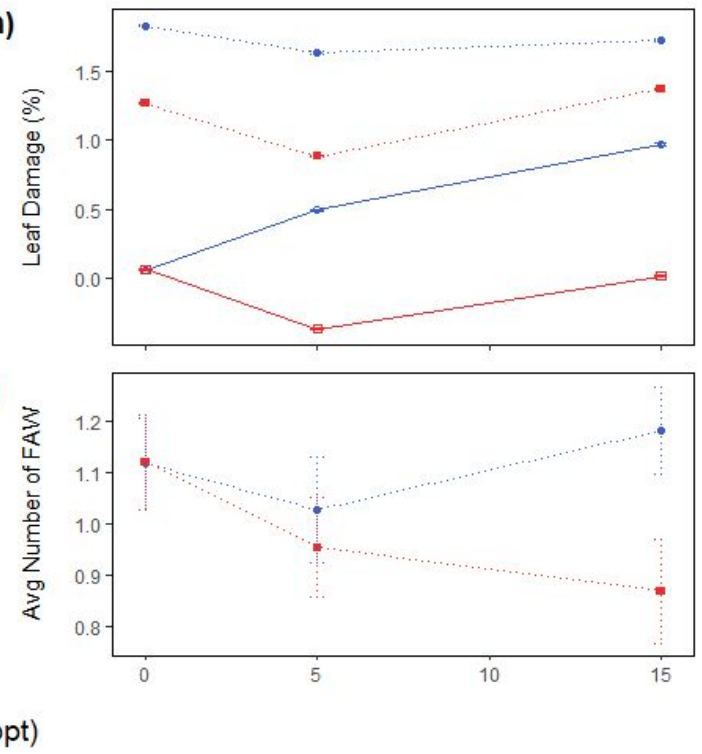

Figure 4 | The effects of salinity and $S$. frugiperda (FAW) presence on the amount of (a) glucose and (b) sucrose in leaf tissues, (c) percent starch in rhizomes, (d) aboveground biomass, (e) specific leaf area, (f) percent leaf water content, (g) leaf toughness, (h) leaf damage from herbivory, (i) mean FAW biomass, (j) and the number of FAW on the plants. Values are represented by the least square means and corresponding standard errors, determined using Kruskal-Wallis analysis. 
(a)

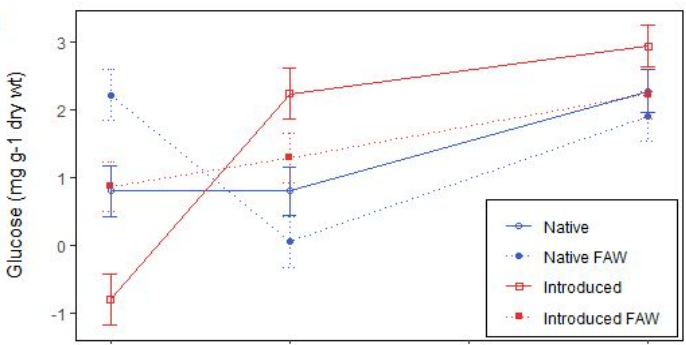

(c)

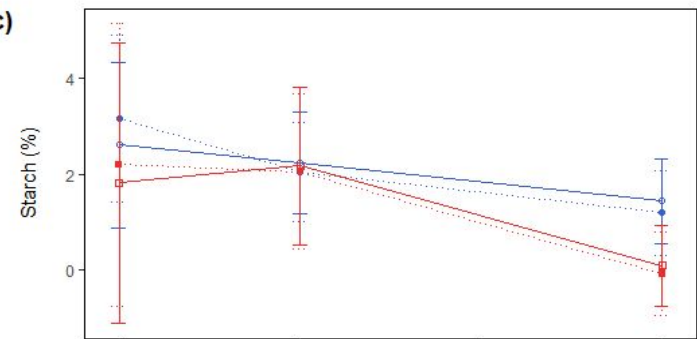

(e)

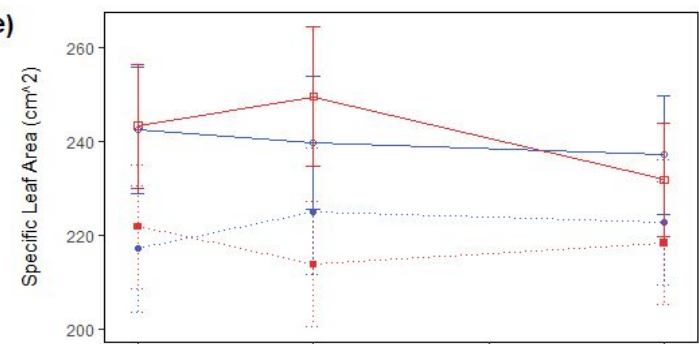

(g)

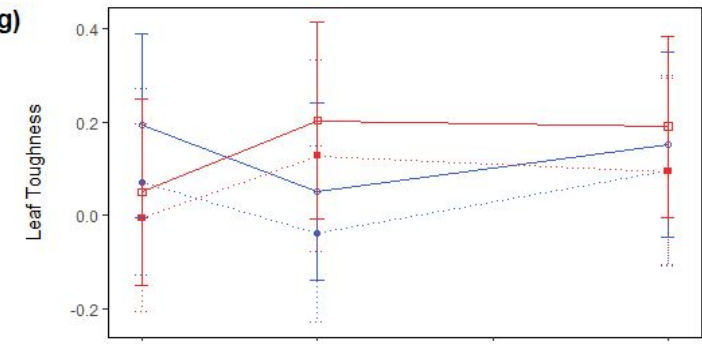

(i)

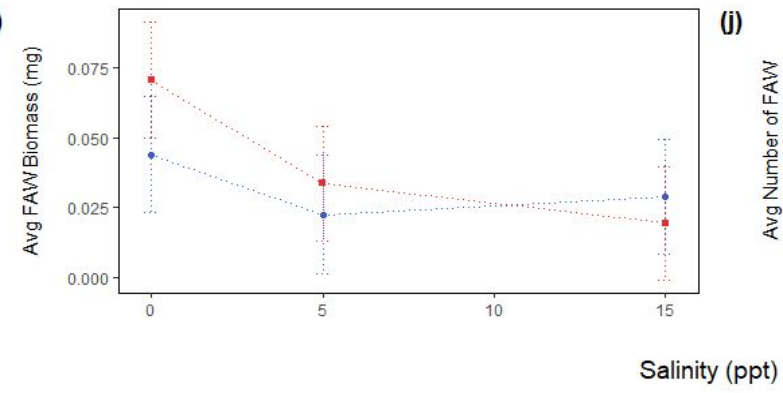

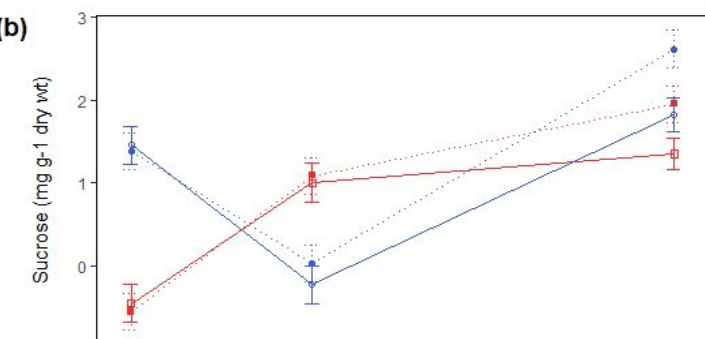

(d)

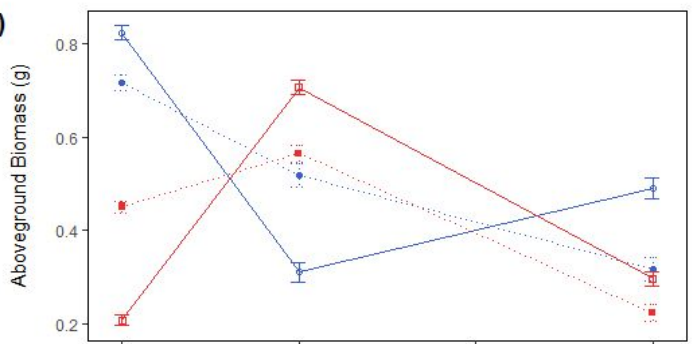

(f)

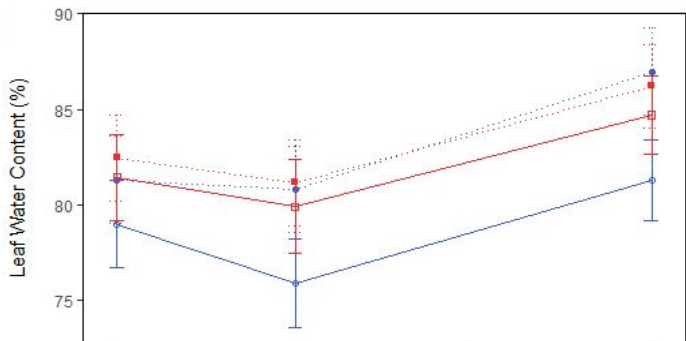

(h)

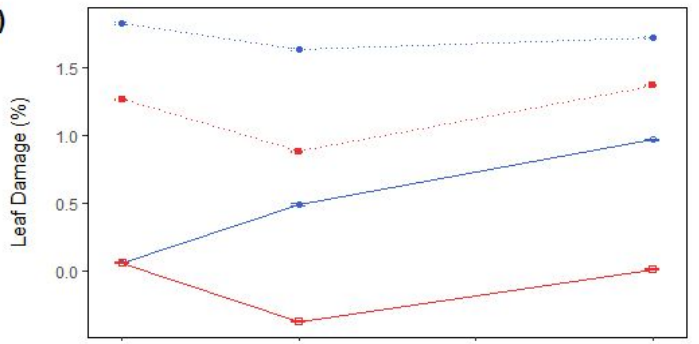

j)

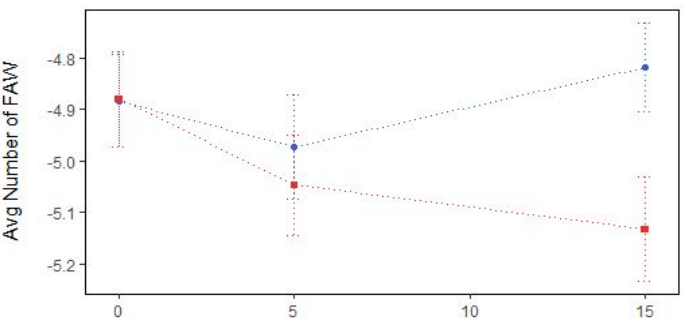

Figure 5 | The effect of salinity and S. frugiperda (FAW) presence on the rate of change between initial and final samplings for the amount of (a) glucose and (b) sucrose in leaf tissues, (c) percent starch in rhizomes, (d) aboveground biomass, (e) specific leaf area, (f) percent leaf water content, (g) leaf toughness, (h) leaf damage, (i) mean $S$. frugiperda biomass, and (j) mean number of $S$. frugiperda larvae. Values are represented by the least square means and corresponding standard errors, determined using Kruskal-Wallis analysis. 


\section{Bibliography}

Alber M., Swenson E., Adamowicz S., et al (2008) "Salt Marsh Dieback: An Overview of Recent Events in the US." Estuarine, Coastal and Shelf Science, 80(1): 1-11.

Albert R. and Popp M. (1977) "Chemical composition of halophytes from the Neusiedler Lake region in Austria.” Oecologia, 27(2): 157-170.

Achenbach L. and Brix H. (2014) "Can differences in salinity tolerance explain the distribution of four genetically distinct lineages of Phragmites australis in the Mississippi River Delta?" Hydrobiologia, 737(1): 5-23

Armstrong J. and Armstrong W. (1999) "Phragmites die-Back: Toxic Effects of Propionic, Butyric and Caproic Acids in Relation to pH.” New Phytologist, 142(2): 201-217.

Ashraf M. and Harris P. (2004) "Potential Biochemical Indicators of Salinity Tolerance in Plants." Plant Science, 166(1): 3-16.

Bhattarai G., Meyerson L., Anderson J., et al (2016a) "Biogeography of a Plant Invasion: Genetic Variation and Plasticity in Latitudinal Clines for Traits Related to Herbivory." Ecological Monographs, 87(1): $57-75$.

Bhattarai G., Meyerson L., and Cronin J. (2016b). "Geographic Variation in Apparent Competition between Native and Invasive Phragmites australis." Ecology, 98(2): 349-358.

Blossey B. (2014) "Identification, development, and release of insect biocontrol agents for the management of Phragmites australis." ERDC/EL CR-14-2. US Army Corps of Engineers, Washington DC.

Canas L. and O'neil R. (1998) “Applications of Sugar Solutions to Maize, and the Impact of Natural Enemies on Fall Armyworm.” International Journal of Pest Management, 44(2): 59-64.

Chambers R., Meyerson L., and Saltonstall K. (1999) "Expansion of Phragmites australis into Tidal Wetlands of North America." Aquatic Botany, 64(3-4): 261-273.

Chambers R., Mozdzer T., and Ambrose J. (1998) "Effects of Salinity and Sulfide on the Distribution of Phragmites australis and Spartina alterniflora in a Tidal Salt-marsh." Aquatic Botany, 62(3): $161-169$.

Cha-Um S., Charoenpanich A., Roytrakul S., et al (2009) "Sugar Accumulation, Photosynthesis and Growth of Two Indica Rice Varieties in Response to Salt Stress." Acta Physiologiae Plantarum, 31(3): 477-486.

Čížková H., Lukavská, J., Přibáň, K. et al. (1996) "Carbohydrate Levels in Rhizomes of Phragmites australis at an Oligotrophic and a Eutrophic Site: A Preliminary Study." Folia Geobotanica Et Phytotaxonomica, 31(1): 111-118.

Č́źžková-Koncalova H., Kvet, J. and Thompson, K. (1992). "Carbon starvation: a key to reed decline in eutrophic lakes.” Aquatic Botany, 43(2): 105-113.

Cronin J., Meyerson L., Kiviat K., et al (2016) "Biological Control of Invasive Phragmites Australis Will Be Detrimental to Native P. australis.” Biological Invasions, 18(9): 2749-2752.

Cronin J., Bhattarai G., Allen W., et al (2015) "Biogeography of a Plant Invasion: Plant-Herbivore Interactions." Ecology, 96(4): 1115-1127. 
Croy J., Meyerson L., Warwick A., et al (2020) "Lineage and Latitudinal Variation in Phragmites australis Tolerance to Herbivory: Implications for Invasion Success." Oikos.

Douglas A. (1993) “The Nutritional Quality of Phloem Sap Utilized by Natural Aphid Populations." Ecological Entomology, 18(1): 31-38.

Douhovnikoff V., Taylor S., Hazelton E., et al (2016) "Maximal Stomatal Conductance to Water and Plasticity in Stomatal Traits Differ between Native and Invasive Introduced Lineages of Phragmites australis in North America." AoB Plants, 8

Dubois M., Gilles K., Hamilton J., et al (1956) "Colorimetric Method for Determination of Sugars and Related Substances.” Analytical Chemistry, 28(3): 350-356.

Engloner A. (2009) "Structure, Growth Dynamics and Biomass of Reed (Phragmites australis) - A Review." Flora - Morphology, Distribution, Functional Ecology of Plants, 204(5): 331-346.

Fogli S., Marchesini R., and Gerdol R. (2002) "Reed (Phragmites australis) Decline in a Brackish Wetland in Italy." Marine Environmental Research, 53(5): 465-479.

Gigante D., Nisi B., Vaselli O., et al (2014) "New Occurrence of Reed Bed Decline in Southern Europe: Do Permanent Flooding and Chemical Parameters Play a Role?" Comptes Rendus Biologies, 337(7-8): 487-498.

Gorai M., Ennajeh M., Khemira H., et al (2010) "Combined Effect of NaCl-Salinity and Hypoxia on Growth, Photosynthesis, Water Relations and Solute Accumulation in Phragmites australis Plants." Flora - Morphology, Distribution, Functional Ecology of Plants, 205(7): 462-470.

Gough L. and Grace J. (1998) "Effects of Flooding, Salinity and Herbivory on Coastal Plant Communities, Louisiana, United States." Oecologia, 117(4): 527-535.

Graneli W., Weisner S., and Sytsma M. (1992) "Rhizome Dynamics and Resource Storage in Phragmites australis." Wetlands Ecology and Management, 1(4): 239-247.

Häfliger P., Schwarzländer M., Blossey B. (2005) “Biology of Platycephala planifrons (Diptera: Chloropidae) and its potential effectiveness as biological control agent for invasive Phragmites australis in North America." Biol Control, 34:302-311

Häfliger P., Schwarzländer M., Blossey B. (2006) “Impact of Archanara geminipuncta (Lepidoptera: Noctuidae) on aboveground biomass production of Phragmites australis." Biol Control $38: 413-421$

Hansen R. (1978) “Shasta ground sloth food habits, Rampart Cave, Arizona.” Paleobiology, 4(3): 302-319.

Hartzendorf T. and Rolletschek H. (2001) "Effects of NaCl-Salinity on Amino Acid and Carbohydrate Contents of Phragmites australis." Aquatic Botany, 69(2-4):195-208.

Hellings S. and Gallagher J. (1992) "The Effects of Salinity and Flooding on Phragmites australis" Journal of Applied Ecology, 29(1): 41-49

Hendrix D. (1993) "Rapid Extraction and Analysis of Nonstructural Carbohydrates in Plant Tissues." Crop Science, 33(6): 1306-1311. 
Kaneko S. (2004) "Within-Plant Vertical Distributions of the Scale Insect Nipponaclerda Biwakoensis and Its Five Parasitoids That Exhibit Frequent Successful Multiparasitism on the Common Reed." Entomological Science, 7(4): 331-339.

Karunaratne S., Asaeda T., and Yutani K. (2004) "Shoot Regrowth and Age-Specific Rhizome Storage Dynamics of Phragmites australis Subjected to Summer Harvesting." Ecological Engineering, 22(2): 99-111.

Keeping M. and Kvedaras O. (2008) "Silicon as a Plant Defense against Insect Herbivory: Response to Massey, Ennos and Hartley.” Journal of Animal Ecology, 77(3): 631-633.

Kiviat E. (2013) "Ecosystem services of Phragmites in North America with emphasis on habitat functions." AoB Plants, 5.

Kiviat E. and Hamilton E. (2001) "Phragmites Use by Native North Americans." Aquatic Botany, 69(2-4): $341-357$.

Konisky R. and Burdick D. (2006) "Effects of stressors on invasive and halophytic plants of New England salt marshes: A framework for predicting response to tidal restoration" Wetlands, 24(2): 434-447

Koppitz H. (2004) "Effects of flooding on the amino acid and carbohydrate patterns of Phragmites australis" Limnologica, 34(1-2): 37-47.

Koppitz H., Dewender M., Ostendorp W., et al (2004b) “Amino Acids as Indicators of Physiological Stress in Common Reed Phragmites australis Affected by an Extreme Flood.” Aquatic Botany, 79(4): $277-294$

Knight I., Wilson B., Gill M., et al (2018) "Invasion of Nipponaclerda biwakoensis (Hemiptera: Aclerdidae) and Phragmites australis Die-Back in Southern Louisiana, USA." Biological Invasions, 20(10): 2739-2744.

Lambert A. and Casagrande R. (2015) "Susceptibility of Native and Non-Native Common Reed to the Non-Native Mealy Plum Aphid (Homoptera: Aphididae) in North America" Environmental Entomology, 36(2): 451-457.

Lambertini C., Mendelssohn I., Gustafsson M., et al (2012) "Tracing the Origin of Gulf Coast Phragmites (Poaceae): A Story of Long-Distance Dispersal and Hybridization.” American Journal of Botany, 99(3): 538-551.

Lissner J. and Schierup H.-H. (1997) "Effects of salinity on the growth of Phragmites australis." Aquatic Botany, 55(4): 247-260

Lissner J., Schierup H.-H., Comin F., et al (1999) "Effect of climate on the salt tolerance of two Phragmites australis populations. Parts I and II." Aquatic Botany, 64(3-4): 317-350.

Lozier J., Roderick G., and Mills N. (2009) "Tracing the invasion history of mealy plum aphid, Hyalopterus pruni (Hemiptera: Aphididae), in North America: A population genetics approach" Biological Invasions, 11(2): 299-314.

Masuko T, Minami A., Iwasaki N., et al (2005) "Carbohydrate Analysis by a Phenol-Sulfuric Acid Method in Microplate Format." Analytical Biochemistry, 339(1): 69-72.

Matoh T., Matsushita N., and Takahashi E. (1998) "Salt Tolerance of the Reed Plant Phragmites communis." Physiologia Plantarum, 72(1): 8-14. 
Matsushita, N. and Matoh, T. (1991) "Characterization of $\mathrm{Na}+$ exclusion mechanisms of salt-tolerant reed plants in comparison with salt-sensitive rice plants.” Physiologia Plantarum, 83(1), 170-176.

Meadows R., and Saltonstall K. (2007) "Distribution of Native and Introduced Phragmites australis in Freshwater and Oligohaline Tidal Marshes of the Delmarva Peninsula and Southern New Jersey." The Journal of the Torrey Botanical Society, 134(1): 99-107.

Meyerson L., Cronin J., Bhattarai G., et al (2016) "Do Ploidy Level and Nuclear Genome Size and Latitude of Origin Modify the Expression of Phragmites Australis Traits and Interactions with Herbivores?" Biological Invasions, 18(9): 2531-2549.

Meyerson L., Lambert A., and Saltonstall K. (2010) "A Tale of Three Lineages: Expansion of Common Reed (Phragmites australis) in the U.S. Southwest and Gulf Coast." Invasive Plant Science and Management, 3(4): 515-520.

Meyerson L., Saltonstall K., and Chambers R. (2009) "Phragmites australis in Eastern North America: a Historical and Ecological Perspective." Human Impacts on Salt Marshes: a Global Perspective, by Mark D. Bertness et al., University of California Press, 57-82.

Meyerson L., Saltonstall K., Windham L., et al (2000) "A Comparison of Phragmites australis in freshwater and brackish marsh environments in North America". Wetlands Ecology and Management, 8: 89-103.

Meyerson L., Pysek P., Lucanova M., et al (2020) "Plant genome size influences stress tolerance of invasive and native plants via plasticity" Ecosphere, 11(5)

Morris D. (1948) "Quantitative Determination of Carbohydrates with Dreywood's Anthrone Reagent." Science, 107: 254-255.

Mozdzer T., Zieman J., and McGlathery K. (2010) "Nitrogen Uptake by Native and Invasive Temperate Coastal Macrophytes: Importance of Dissolved Organic Nitrogen." Estuaries and Coasts, 33(3):784-797.

Price A., Fant J., and Larkin D. (2013) "Ecology of Native vs. Introduced Phragmites Australis (Common Reed) in Chicago-Area Wetlands." Wetlands, 34(2): 369-377.

Raessler M. (2011) "Sample preparation and current applications of liquid chromatography for the determination of non-structural carbohydrates in plants" TrAC - Trends Anal. Chem., 30: $1833-1843$.

Reale L., Gigante D., Landucci F., et al (2012) "Morphological and Histo-Anatomical Traits Reflect Die-Back in Phragmites australis (Cav.) Steud.” Aquatic Botany, 103:122-128.

Renault S., Wolfe S., Markham J. et al (2016) "Increased Resistance to a Generalist Herbivore in a Salinity-Stressed Non-Halophytic Plant." AoB Plants, 8.

Rodríguez M., and Brisson J. (2015) "Pollutant Removal Efficiency of Native versus Exotic Common Reed (Phragmites australis) in North American Treatment Wetlands." Ecological Engineering, 74: 364-370.

Salgado C. and Pennings S. (2005) "Latitudinal Variation In Palatability Of Salt-Marsh Plants: Are Differences Constitutive?” Ecology, 86(6): 1571-1579. 
Saltonstall K. (2002) "Cryptic Invasion by a Non-Native Genotype of the Common Reed, Phragmites australis, into North America." Proceedings of the National Academy of Sciences, 99: 2445-2449.

Schwarzländer M., and Häfliger P. (2000) "Shoot flies, gall midges, and shoot and rhizome mining moths associated with common reed in Europe and their potential for biological control." In: Proceedings of the X international symposium on biological control of weeds, 397-420

Smith D., Paulsen G., and Raguse C. (1964) "Extraction of Total Available Carbohydrates from Grass and Legume Tissue." Plant Physiology, 39(6): 960-962.

Swearingen J. and Saltonstall K. (2010) "Phragmites Field Guide: Distinguishing Native and Exotic Forms of Common Reed (Phragmites australis) in the United States" Plant Conservation Alliance, Weeds Gone Wild.

Vasquez E., Glenn E., Brown J., et al (2005) "Salt Tolerance Underlies the Cryptic Invasion of North American Salt Marshes by an Introduced Haplotype of the Common Reed Phragmites Australis (Poaceae)." Marine Ecology Progress Series, 298: 1-8.

Vretare V., Weisner S., Strand J., et al (2001) "Phenotypic Plasticity in Phragmites australis as a Functional Response to Water Depth.” Aquatic Botany, 69(2-4): 127-145.

Tang F., Wang T., and Zhu J. (2014) "Carbohydrate Profiles during Cotton (Gossypium Hirsutum L.) Boll Development and Their Relationships to Boll Characters." Field Crops Research, 164: 98-106.

Tewksbury L., Casagrande R., Blossey B., et al (2002) "Potential for biological control of Phragmites australis in North America." Biol Control, 23(2):191-212

Tylová E., Steinbachova L., Votrubova O., et al (2008) "Different Sensitivity of Phragmites Australis and Glyceria Maxima to High Availability of Ammonium-N." Aquatic Botany, vol. 88(2): 93-98.

Wersal R., Madsen J., and Cheshier, J. (2013) "Seasonal Biomass and Starch Allocation of Common Reed (Phragmites australis) (Haplotype I) in Southern Alabama, USA". Invasive Plant Science and Management. 6: 140-146.

Wijte A., and Gallagher J. (1996) "Effect of Oxygen Availability and Salinity on Early Life History Stages of Salt Marsh Plants. I. Different Germination Strategies of Spartina alterniflora and Phragmites australis (Poaceae)." American Journal of Botany, 83: 1337

Xiangbin G., Youhua W., Zhiguo Z., et al (2012) "Response of Cotton Fiber Quality to the Carbohydrates in the Leaf Subtending the Cotton Boll." Journal of Plant Nutrition and Soil Science, 175(1): $152-160$.

Zhao D. and Oosterhuis D. (1998) "Cotton Responses to Shade at Different Growth Stages: Nonstructural Carbohydrate Composition.” Crop Science, 38: 